\title{
日本オージオロジ一学会用語
}

1. 適用範囲 ここに定めた用語は，日本オージオロジー学会およびこれに関連した聴覚・音響の分 野において用いるおもな用語で，その読み方，および用語の意味について規定する。なお参考 のために対応英語を示す。

2. 日本オージオロジー学会用語 おもな用語についてつぎのように定める。

A. 音響一般

\begin{tabular}{|c|c|c|c|}
\hline $\begin{array}{l}\text { 用 語 } \\
\text { 読 み 方 }\end{array}$ & 味 & 対応英語 (参考) & 参考 - 補 足 \\
\hline $\begin{array}{l}\text { 音（おと） } \\
\text { 音響(おんきょう) }\end{array}$ & $\begin{array}{l}\text { 音波（弾性波）又はそれによって起こされる聴 } \\
\text { 覚的感覚。 } \\
\text { 備考 すべての音波（弾性波）が聴覚的感覚を } \\
\\
\text { ひき起こすとは限らない。例えば超音波。 }\end{array}$ & sound & $\begin{array}{r}\text { JIS Z8106-1983 } \\
1008\end{array}$ \\
\hline 音 響 学 & 音に関する科学。 & acoustics & 1021 \\
\hline $\begin{array}{ll}\text { 音 } & \text { 波 } \\
\text { 弾 } & \text { 性 }\end{array}$ & $\begin{array}{l}\text { 弾性媒質中における, 圧力, 応力, 粒子変位, } \\
\text { 粒子速度などの振動, 及びこれらの振動の伝搬 } \\
\text { 現象。 }\end{array}$ & $\begin{array}{l}\text { sound wave, } \\
\text { elastic wave }\end{array}$ & 1034 \\
\hline 期 & $\begin{array}{l}\text { 周期的現象において, 同一状態が再現するまで } \\
\text { に経過する最小時間間隔。 } \\
\text { 備考 量記号は } T \text {, 単位記号はs。 }\end{array}$ & period & 1070 \\
\hline 周 期 的 & $\begin{array}{l}\text { 一定の時間間隔をおいて, 現象が繰り返される } \\
\text { ことの形容。なお, 独立変数として時間以外の } \\
\text { もの, 例えば位置座標をとる場合もある。 }\end{array}$ & periodic & 1071 \\
\hline $\begin{array}{ll}\text { 周 } & \text { 波 } \\
\text { 数 } \\
\text { 振 }\end{array}$ & $\begin{array}{l}\text { 周期的現象が毎秒繰り返される回数。その值は } \\
\text { 周期の逆数。 } \\
\text { 㣁考 量記号は } f \text { 又は } v \text {, 単位記号は } \mathrm{Hz} \text { 。 }\end{array}$ & frequency & 1076 \\
\hline へルッ & $\begin{array}{l}\text { 振動数または周波数の単位記号で, 単位時間 } 1 \\
\text { 秒あたりの周波数を示す。単位記号は } \mathrm{Hz} \text { 。 } \\
\text { 備考 以前使われたサイクル/秒におなじ。 } \\
\text { 1960年, 国際度量衡会議で決められた統 } \\
\text { 一単位記号。 }\end{array}$ & hert $z$ & $\begin{array}{r}\text { JIS Z8202-1978 } \\
7-\quad 22\end{array}$ \\
\hline サイクル & $\begin{array}{l}1 \text { 周期の間に起こる変化の全過程。 } \\
\text { なお, サイクル毎秒をへルツ（単位記号は } \mathrm{Hz} \text { ) } \\
\text { という。 }\end{array}$ & cycle & $\begin{array}{r}\text { JIS Z8106-1983 } \\
1063\end{array}$ \\
\hline 可聴周波数 & $\begin{array}{l}\text { 正常な聴力を持つ人が聞くことができる周波数 } \\
\text { (振動数)。大略 } 16 \mathrm{~Hz} \text { から } 20 \mathrm{~Hz} \text { までの周波数 } \\
\text { (振動数)。 }\end{array}$ & audio frequency & 1037 \\
\hline $\begin{array}{l}\text { 超 音 波 } \\
\text { (ちょうおんぱ) }\end{array}$ & $\begin{array}{l}\text { 正常な聴力を持つ人に，聴感覚を生じないほど } \\
\text { 周波数 (振動数) が高い音波 (弾性波)。 }\end{array}$ & $\begin{array}{l}\text { ultrasonic wave. } \\
\text { ultrasound }\end{array}$ & 1095 \\
\hline 超低周波数 & 可聴周波数より低い周波数。 & infrasonic frequency & 1096 \\
\hline
\end{tabular}




\begin{tabular}{|c|c|c|c|}
\hline $\begin{array}{c}\text { 用 語 } \\
\text { 読 み 方 }\end{array}$ & 味 & 対応英語 (参考) & 参考 · 補 足 \\
\hline 波 & $\begin{array}{l}\text { 等方性の媒質中を進行する周期的な波動におい } \\
\text { て, } 1 \text { 周期だけ位相差がある二つの波面の垂直 } \\
\text { 距離。 } \\
\text { 備考 量記号は } \lambda, \text { 単位記号は } \mathrm{m}_{\text {。 }}\end{array}$ & wavelength & $\begin{array}{r}\text { JIS Z8106-1983 } \\
1119\end{array}$ \\
\hline 振 & 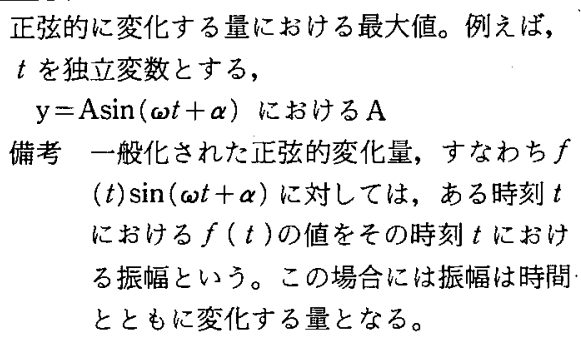 & amplitude & 1084 \\
\hline 音の強さ & $\begin{array}{l}\text { 音場中の } 1 \text { 点において, 音波の進行方向に垂直 } \\
\text { な単位面積を, 単位時間に通過する音波のエネ } \\
\text { ルギー。 } \\
\text { 備考 量記号は } I \text { 又は } J \text {, 単位記号は } \mathrm{W} / \mathrm{m}^{2} \text { 。 }\end{array}$ & sound intensity & 1011 \\
\hline 音の強さのレベル & $\begin{array}{l}\text { ある音の強さと基準の音の強さとの此の常用対 } \\
\text { 数の } 10 \text { 倍。基準の音の強さは空気中の音の場合, } \\
1 \mathrm{pW} / \mathrm{m}^{2} \text { 。 } \\
\text { 備考 量記号は } L_{1} \text {, 単位記号は } \mathrm{dB}_{\text {。 }}\end{array}$ & sound intensity level & 1012 \\
\hline デシベル & 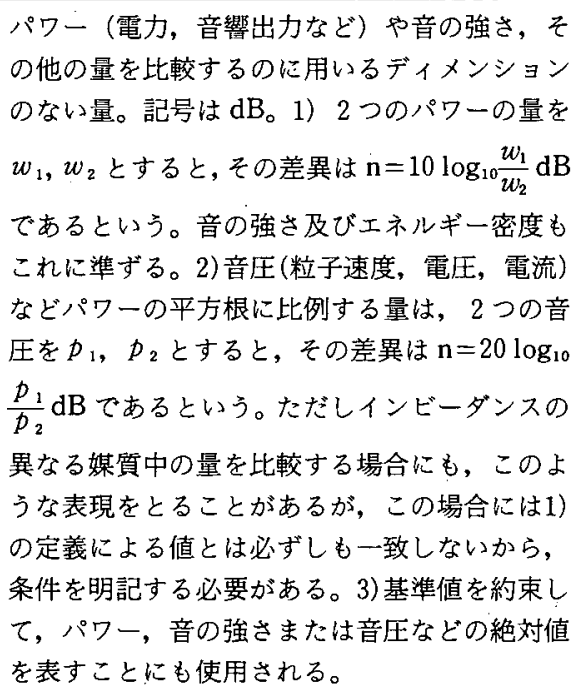 & decibel & JIS Z8202-1978 \\
\hline $\begin{array}{l}\text { 音＼cjkstart圧 } \\
\text { (おんあつ) }\end{array}$ & $\begin{array}{l}\text { 媒質中の音波によって生じる媒質内圧力の静圧 } \\
\text { からの変化分。音圧は臨時值, 波高值又は実効 } \\
\text { 值で表す。 } \\
\text { 備考 量記号は } p \text { 又は } p_{a} \text {, 単位記号は } \mathrm{Pa}(= \\
\left.\mathrm{N} / \mathrm{m}^{2}\right) \text { 。 }\end{array}$ & sound pressure & $\begin{array}{r}\text { JIS Z8106-1983 } \\
1014\end{array}$ \\
\hline & & & \\
\hline
\end{tabular}




\begin{tabular}{|c|c|c|c|}
\hline $\begin{array}{l}\text { 用 語 } \\
\text { 読 み 方 }\end{array}$ & 味 & 対応英語 (参考) & 参考・補足 \\
\hline パスカル & $\begin{array}{l}\text { 圧力, 応力の単位。単位記号は } \mathrm{Pa} \text { 。 } \\
1 \mathrm{~Pa}=1 \mathrm{~N} / \mathrm{m}^{2} \text { 。 }\end{array}$ & pascal & $\begin{array}{r}\text { JIS Z8202-1978 } \\
7-8 \mathrm{a}\end{array}$ \\
\hline マイクロパール & $\begin{array}{l}\text { 圧力の単位の } 1 \text { つで, 音圧を表すときに用いら } \\
\text { れたが現在は使わない。単位記号は は } \mu \text { bar } \\
\left(1 \mu \mathrm{bar}=10^{-1} \mathrm{~Pa}=10^{-1} \mathrm{~N} / \mathrm{m}^{2}=1 \mathrm{dyne} / \mathrm{cm}^{2}=\right. \\
\left.10^{-1} \mathrm{mbar}\right) 。\end{array}$ & microbar & \\
\hline 音圧レベル & $\begin{array}{l}\text { ある音の音压と基準音圧との比の常用対数の } 20 \\
\text { 倍。基準音圧は空気中の音の場合 } 20 \mu \mathrm{Pa}_{\text {。 }} \\
\text { 備考 量記号は } L_{\mathrm{p}} \text {, 単位記号は } \mathrm{dB} \text { 。音压レべ } \\
\text { ルであることを明示するためには } \mathrm{dB} \\
\mathrm{SPL} \text { と書く。 }\end{array}$ & sound pressure level & $\begin{array}{r}\text { JIS Z8106-1983 } \\
1016\end{array}$ \\
\hline $\begin{array}{l}\text { 音压スペクトルレ } \\
\text { ベル }\end{array}$ & $\begin{array}{l}\text { 連続スペクトルをもった音のある周波数を中心 } \\
\text { とした幅 } 1 \mathrm{~Hz} \text { の周波数帯域内に含まれる成分 } \\
\text { の音圧レベル。. }\end{array}$ & $\begin{array}{l}\text { spectrum pressure } \\
\text { level }\end{array}$ & 1015 \\
\hline バンド音圧レベル & $\begin{array}{l}\text { ある周波数帯域内に含まれる音の音圧レベル。 } \\
\text { 例えば, その周波数帯域の幅が } 1 \text { オクターブで } \\
\text { あるときには, オクターブバンド音圧レベルと } \\
\text { いう。 } \\
\text { 備考 単位記号は } \mathrm{dB}_{\text {。 }}\end{array}$ & band pressure level & 1127 \\
\hline $\begin{array}{l}\text { 音響スペクトル } \\
\text { 音のスペクトル }\end{array}$ & $\begin{array}{l}\text { 音の成分の音圧, 音の強さなどを周波数の関数 } \\
\text { として示したもの。 }\end{array}$ & sound spectrum & 1027 \\
\hline 位 相 & $\begin{array}{l}\text { 周期的現象においてサイクル上の位置を示す } \\
\text { 量。 } \\
\text { 例えば, } \mathrm{y}=\mathrm{A} \sin (\omega t+\alpha) \text { では }(\omega t+\alpha) \text { 。 }\end{array}$ & phase & 1003 \\
\hline 位 相 差 & $\begin{array}{l}\text { 同一周波数（振動数）の二つの周期的現象の同 } \\
\text { 一時刻における位相の差。 }\end{array}$ & phase difference & 1004 \\
\hline $\begin{array}{l}\text { 純 音 } \\
(し ゙ ゅ ん お ん) ~\end{array}$ & 瞬時音圧が，時間の単一正弦関数である音。 & $\begin{array}{l}\text { pure sound, } \\
\text { pure tone, } \\
\text { simple tone }\end{array}$ & 1078 \\
\hline 複 合 音 & $\begin{array}{l}\text { 周波数の異なる幾つかの純音からなる音。 } \\
\text { 備考 この用語は主として可聴周波数の音に対 } \\
\text { して用いる。 }\end{array}$ & $\begin{array}{l}\text { complex sound, } \\
\text { complex tone }\end{array}$ & 1134 \\
\hline 複 合 波 & 周波数の異なる幾つかの正弦波からなる波。 & complex wave & 1135 \\
\hline 部 分 音 & 複合音を構成する各純音 & partial & 1137 \\
\hline $\begin{array}{l}\text { 基 本 音 } \\
\text { (きほん扔ん) }\end{array}$ & $\begin{array}{l}\text { 複合音の成分中, 基本周波数（振動数）をもつ } \\
\text { 成分。 } \\
\text { 備考 この用語は主として可聴周波数の音に対 } \\
\qquad し て \text { 用いる。 }\end{array}$ & fundamental & 1042 \\
\hline & & & \\
\hline
\end{tabular}




\begin{tabular}{|c|c|c|c|}
\hline $\begin{array}{l}\text { 用 語 } \\
\text { 読 み 方 }\end{array}$ & 意 & 対応英語 (参考) & 参考・補足 \\
\hline 基本周波数 & $\begin{array}{l}\text { (1) 周期的複合波では，その周期に相当する周 } \\
\text { 波数（振動数)。 } \\
\text { (2) 周期的でない複合波では，その成分中最小 } \\
\text { の周波数 (振動数)。 }\end{array}$ & fundamental frequency & $\begin{array}{r}\text { JIS Z8106-1983 } \\
1043\end{array}$ \\
\hline $\begin{array}{l}\text { 上 音 } \\
\text { (じょう扔ん) }\end{array}$ & $\begin{array}{l}\text { 複合音において基本音以外の部分音。その周波 } \\
\text { 数（振動数）の一番少ないものから順に第 } 1 \text { 上 } \\
\text { 音, 第 } 2 \text { 上音……という。複合音が周期的であ } \\
\text { って,第 } 2 \text { 倍音をもてばそれは第 } 1 \text { 上音になる。 }\end{array}$ & overtone & 1079 \\
\hline 倍 音 & $\begin{array}{l}\text { 周期的複合音の各成分中, 基本音以外のもの。 } \\
\text { 第 } \mathrm{n} \text { 倍音とは, 基本周波数（振動数）の } \mathrm{n} \text { 倍の } \\
\text { 周波数（振動数）をもつものをいう。 } \\
\text { 備考 この用語は主として可聴周波数の音に対 } \\
\text { して用いる。 }\end{array}$ & harmonic & 1115 \\
\hline $\begin{array}{l}\text { 謂 波 } \\
\text { (ちょうは) }\end{array}$ & $\begin{array}{l}\text { 周期的複合波の各成分。基本波も含む。調波の } \\
\text { 周波数（振動数）は基本周波数（振動数）の整 } \\
\text { 数倍である。 }\end{array}$ & harmonic & 1097 \\
\hline 調和成分 & $\begin{array}{l}\text { 複合音の成份のうち，その周波数（振動数）が } \\
\text { 倍音関係にあるもの。 }\end{array}$ & harmonic component & 1098 \\
\hline 高 調 波 & $\begin{array}{l}\text { 周期的複合波の各成分中, 基本波以外のもの。 } \\
\text { 第 } \mathrm{n} \text { 高調波とは, 基本周波数（の } \mathrm{n} \text { 倍の周波数 } \\
\text { 振動数）をもつもの。 }\end{array}$ & harmonic & 1058 \\
\hline $\begin{array}{l}\text { 低 調 波 } \\
\text { 分数調波 } \\
\text { サフハーモニック }\end{array}$ & $\begin{array}{l}\text { 周期的強制振動をしている系の振動成分のう } \\
\text { ち, 外力の基本周波数（振動数）の整数分の一- } \\
\text { の周波数（振動数）をもつもの。 }\end{array}$ & subharmonic & 1101 \\
\hline $\begin{array}{ll}\text { 共 } & \text { 振 } \\
\text { 共 } & \text { 鳴 }\end{array}$ & $\begin{array}{l}\text { 損失が少ない振動系の強制振動において, 外力 } \\
\text { の大きさを一定のまま振動数（周波数）を変化 } \\
\text { したときに, 振動系の固有振動数（周波数）の } \\
\text { 付近で, 変位, 速度, 圧力などが極大值をとる } \\
\text { 現象。また, そのような極大值をとった状態。 } \\
\text { 備考 共鳴という用語は, 主として可聴周波数 } \\
\text { の音に対して用いる。 }\end{array}$ & resonance & 1052 \\
\hline $\begin{array}{l}\text { 共振周波数 } \\
\text { 共鳴周波数 } \\
\text { 共鳴振動数 }\end{array}$ & 共振（共鳴）現象が起こる周波数（振動数）。 & $\begin{array}{l}\text { resonance frequency, } \\
\text { resonant frequency }\end{array}$ & 1053 \\
\hline うな $\eta$ & $\begin{array}{l}\text { 周波数（振動数）のわずかに異なる二つの正弦 } \\
\text { 波が重ね合わされたときに生じる振幅の周期的 } \\
\text { 変化。1 秒間に生じる振幅の変化の回数は, 元 } \\
\text { の波の周波数 (振動数) の差に等しい。 }\end{array}$ & beats & 1006 \\
\hline $\begin{array}{l}\text { 定在 波 } \\
\text { (ていざいは) }\end{array}$ & $\begin{array}{l}\text { 同一周波数 (振動数) の進行波の干渉によって } \\
\text { 生じる空間的な振幅分布の定まった波。 }\end{array}$ & standing wave & 1099 \\
\hline
\end{tabular}




\begin{tabular}{|c|c|c|c|}
\hline $\begin{array}{l}\text { 用 語 } \\
\text { 読 み 方 }\end{array}$ & 意 & 対応英語 (参考) & 参考 • 補 足 \\
\hline $\begin{array}{l}\text { 定常波 } \\
\text { (ていじょうは) }\end{array}$ & $\begin{array}{l}\text { すべての点で全音響パワーの流れが零であるよ } \\
\text { うな定在波。空間に固定した節をもつ。 } \\
\text { 備考 定常波は実際には近似的にしか実現され } \\
\text { ない。 }\end{array}$ & stationary wave & $\begin{array}{r}\text { JIS Z8106-1983 } \\
1100\end{array}$ \\
\hline ドプラ効果 & $\begin{array}{l}\text { 波動源, 観測点又は媒質が移動することによっ } \\
\text { て, 波動の観測された周波数（振動数）が変化 } \\
\text { する現象。 }\end{array}$ & Doppler effect & 1110 \\
\hline 雑音 & $\begin{array}{l}\text { (1) 周期性がなく部分音に分解できない音。 } \\
\text { (2) 主として電気回路における望ましくない電 } \\
\text { 気的じょう (搝) 乱。 }\end{array}$ & noise & 1064 \\
\hline $\begin{array}{l}\text { 白色雑音 } \\
\text { (はくしょくざつ } \\
\text { おん) }\end{array}$ & $\begin{array}{l}\text { 連続スペクトルをもつ雑音で, 所定の周波数範 } \\
\text { 囲内で, 単位周波数带域 }(1 \mathrm{~Hz}) \text { に含まれる成分 } \\
\text { の強さが周波数に無関係に一定である音。電気 } \\
\text { 回路におい搝同様な性質をもつ波形にも使用さ } \\
\text { れる。 }\end{array}$ & white noise & 1118 \\
\hline ピンクノイズ & $\begin{array}{l}\text { 連続スペクトルをもつ雑音で, 所定の周波数範 } \\
\text { 囲内で, } 1 \text { オクターブ当たりに含まれる成分の } \\
\text { 強さが周波数位置に関係なく一定である音。 }\end{array}$ & pink noise & 1133 \\
\hline 帯域雑音 & $\begin{array}{l}\text { ある限られた周波数範囲の連続スペクトルをも } \\
\text { つ雑音。 }\end{array}$ & band-pass of noise & \\
\hline $\begin{array}{l}\text { 震 音 } \\
\text { (しんおん) }\end{array}$ & $\begin{array}{l}\text { 周波数が, ある範囲内を連続的にしかも周期的 } \\
\text { に変化する音。 }\end{array}$ & warble tone & 1081 \\
\hline 残 響 & $\begin{array}{l}\text { 音源が停止した後に多重反射によって音が持続 } \\
\text { する現象。 }\end{array}$ & reverberation & 1065 \\
\hline 残響時間 & $\begin{array}{l}\text { 容器（室）の中の音のエネルギー密度が定常の } \\
\text { 状態にあるとき, 音源を停止後, } 60 \mathrm{~dB} \text { だ減少 } \\
\text { する時間。 } \\
\text { 備考 量記号は } T \text {, 単位記号は } \mathrm{s} \text { 。 }\end{array}$ & reverberation time & 1066 \\
\hline 馶音 & $\begin{array}{l}\text { 望ましくない音。例えば, 音声, 音楽などの伝 } \\
\text { 達を妨害したり, 生活に障害, 苦痛を与えたり } \\
\text { する音。 }\end{array}$ & noise & 1088 \\
\hline 騒音レベル & 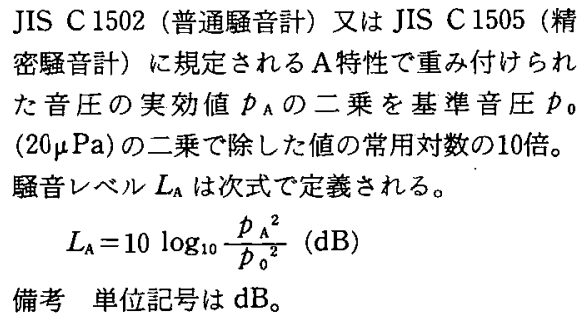 & $\begin{array}{l}\text { A-weighted sound } \\
\text { pressure level }\end{array}$ & $\begin{array}{r}1089 \\
\text { 騒音レベルの単位と } \\
\text { して計量法では,木ン } \\
\text { が使われることもあ } \\
\text { るので注意が必要で } \\
\text { ある。 }\end{array}$ \\
\hline
\end{tabular}




\begin{tabular}{|c|c|c|c|}
\hline $\begin{array}{l}\text { 用 語 } \\
\text { 読 み 方 }\end{array}$ & 味 & 対応英語 (参考) & 参考 - 補足 \\
\hline 等洒騒音レベル & 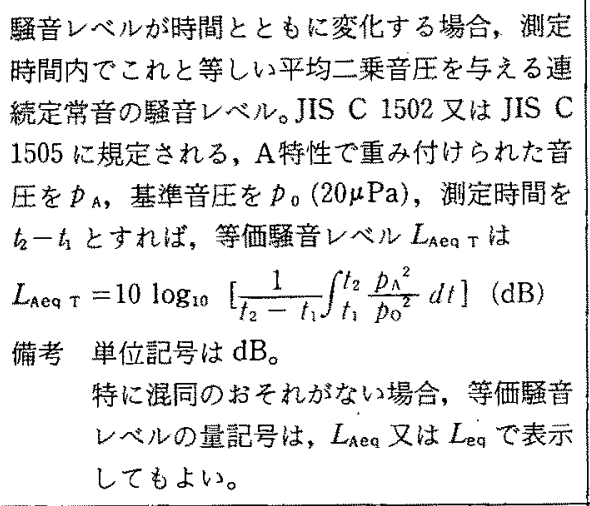 & $\begin{array}{l}\text { equivalent continuous } \\
\text { A-weighted sound } \\
\text { pressure level }\end{array}$ & $\begin{array}{r}\text { JIS Z8106-1983 } \\
1106\end{array}$ \\
\hline $\begin{array}{l}\text { 暗 騒 音（あんそ } \\
\text { うおん） }\end{array}$ & $\begin{array}{l}\text { ある音を対象としたとき，その音がないときの } \\
\text { その場所における騒音。 }\end{array}$ & background noise & 1002 \\
\hline 動 & $\begin{array}{l}\text { ある量の大きさが，時間とともにある基準の值 } \\
\text { より大きくなったり小さくなったりする現象。 }\end{array}$ & $\begin{array}{l}\text { oscillation, } \\
\text { vibration }\end{array}$ & 1082 \\
\hline 振動レベル & $\begin{array}{l}\text { JIS C } 1510 \text { (振動レベル計)に規定される振動感 } \\
\text { 覚補正を行った振動加速度の実効値を, 基準の } \\
\text { 振動加速度 }\left(10^{-5} \mathrm{~m} / \mathrm{s}^{2}\right) \text { で除した値の常用対数 } \\
\text { の20倍。 } \\
\text { 備考 単位記号は } \mathrm{dB} \text { 。 }\end{array}$ & vibration level & 1083 \\
\hline 音響イミタンス & $\begin{array}{l}\text { 音響インピーダンスと音響アドミタンスを包括 } \\
\text { する概念。 } \\
\text { 備考 音響アドミタンスは音響インピーダンス } \\
\text { の逆数。 }\end{array}$ & acoustic immitance & 2017 \\
\hline $\begin{array}{l}\text { 音響インピーダン } \\
\text { ス }\end{array}$ & $\begin{array}{l}\text { 音場において波面に平行な有限な面を考え, そ } \\
\text { の面における複素数で表わした音圧とその面を } \\
\text { 通過する複素数で表わした体積速度との比。 } \\
\text { 倩考 量記号は } \mathrm{Za} \text {, 単位記号は } \mathrm{Pa} \cdot \mathrm{s} / \mathrm{m}^{3}(=\mathrm{N} . \\
\left.\mathrm{s} / \mathrm{m}^{3}\right) \text { 。 }\end{array}$ & acoustic impedance & 1017 \\
\hline 音響抵抗 & $\begin{array}{l}\text { 音響インピーダンスの実数部。 } \\
\text { 備考 単位記号は } \mathrm{Pa} \cdot \mathrm{s} / \mathrm{m}^{3} \text { 。 }\end{array}$ & acoustic resistance & 1028 \\
\hline 音響リアクタンス & $\begin{array}{l}\text { 音響インピーダンスの虚数部。 } \\
\text { 静考 単位記号は } \mathrm{Pa} \cdot \mathrm{s} / \mathrm{m}^{3} \text { 。 }\end{array}$ & acoustic reactance & 1029 \\
\hline 音響スチフネス & $\begin{array}{l}\text { 振動角周波数で除したものが音響リアクタンス } \\
\text { となるような量。 } \\
\text { 備考 単位記号は } \mathrm{Pa} / \mathrm{m}^{3} \text { 。 }\end{array}$ & acoustic stiffness & 1026 \\
\hline $\begin{array}{l}\text { 音響コンプライア } \\
\text { ンス }\end{array}$ & $\begin{array}{l}\text { 音響スチフネスの逆数。 } \\
\text { 䚛考 単位記号は } \mathrm{m}^{3} / \mathrm{Pa}\end{array}$ & acoustic compliance & 1022 \\
\hline $\begin{array}{l}\text { 音 場 } \\
\text { (おんじょう) }\end{array}$ & 音波の存在する空間。 & sound field & 1032 \\
\hline
\end{tabular}




\begin{tabular}{|c|c|c|c|}
\hline $\begin{array}{l}\text { 用 語 } \\
\text { 読 み 方 }\end{array}$ & 意 & 対応英語 (参考) & 参考 - 補足 \\
\hline $\begin{array}{l}\text { 自由音場 } \\
\text { (じゅうおんじょ } \\
\text { う) }\end{array}$ & $\begin{array}{l}\text { 等方性かつ均䓄筫の媒筫中で境界の影響を無視で } \\
\text { きる音場。 }\end{array}$ & free (sound) field, & $\begin{array}{r}\text { JIS Z8107-1983 } \\
1069\end{array}$ \\
\hline
\end{tabular}

\section{B. 音響機器}

\begin{tabular}{|c|c|c|c|}
\hline $\begin{array}{l}\text { 用 語 } \\
\text { 読 み 方 }\end{array}$ & 意 & 対応英語 (参考) & - 補 足 \\
\hline イヤホン & $\begin{array}{l}\text { 電気信号を音響信号に変換する電気音響変換器 } \\
\text { で, 耳に当て又は差し込んで使用するもの。 }\end{array}$ & earphone & $\begin{array}{r}\text { JIS Z8107-1984 } \\
2006\end{array}$ \\
\hline 受 話 器 & $\begin{array}{l}\text { (1) イヤホンに同じ。 } \\
\text { (2) 電話機に用いるイヤホン。 }\end{array}$ & $\begin{array}{l}\text { (1) earphone } \\
\text { (2) telephone ear- } \\
\text { phone }\end{array}$ & 2069 \\
\hline 挿入イヤホン & 外耳道に挿入して用いる構造の小形イヤホン。 & insert earphone & 2091 \\
\hline $\begin{array}{l}\text { 耳輹いイヤホン } \\
\text { (みみおおいいや } \\
\text { ほん) }\end{array}$ & 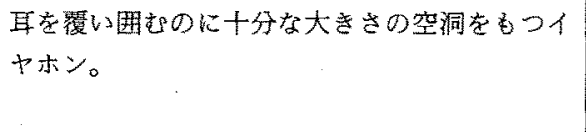 & circumaural earphone & 2154 \\
\hline $\begin{array}{l}\text { 耳載せイヤホン } \\
\text { (みみのせいやほ } \\
\text { ん) }\end{array}$ & 外耳の外側に装着する棈造のイヤホン & supraaural earphone & 2155 \\
\hline ヘッドホン & $\begin{array}{l}1 \text { 個又は } 2 \text { 個のイヤホンをへッドバンドと組み } \\
\text { 合わせたもの。 }\end{array}$ & headphone & 2139 \\
\hline $\begin{array}{l}\text { 骨筫受話器 } \\
\text { (こつどうじゅわ } \\
\text { き) }\end{array}$ & 頭の骨を振動させて聴感を起こさせる受話器。 & $\begin{array}{l}\text { bone (conduction) } \\
\text { vibrator }\end{array}$ & 2044 \\
\hline $\begin{array}{l}\text { 音さ（叉） } \\
\text { (おんさ) }\end{array}$ & U字形の振動体で, 純音を発生するもの。 & tuning fork & 2024 \\
\hline $\begin{array}{l}\text { 防音保護具, イヤ } \\
\text { プロテクタ }\end{array}$ & $\begin{array}{l}\text { 耳を覆うか又は外耳道に括入して, 鲶覚器官を } \\
\text { 強い騒音から保護するために用いる器具。 }\end{array}$ & ear protector & 2141 \\
\hline カプラ & $\begin{array}{l}\text { 電気音響変換器や電気機械変換器の校正又は試 } \\
\text { 験を行うために,二つつ変換器を結合する装䁂。 }\end{array}$ & coupler & 2029 \\
\hline イヤホンカプラ & $\begin{array}{l}\text { イヤホンの試験に用いる音響カプラで, 音压を } \\
\text { 測定するマイクロホンを備えるもの。 }\end{array}$ & earphone coupler & 2007 \\
\hline 意響カプラ & $\begin{array}{l}\text { イヤンリヤイクロホンの校正に用いる, 所定 } \\
\text { の形状及び容積の空洞をもつカプラ。 }\end{array}$ & acoustic coupler & 2018 \\
\hline ピストンホン & $\begin{array}{l}\text { 一定の変位と周波数をもつピストンを用いて, } \\
\text { 規定された音圧を発生するマイクロホン校正用 } \\
\text { 音響カプラ。 }\end{array}$ & pistonphone & 2127 \\
\hline $\begin{array}{l}\text { メカニカルカプ } \\
\text { ラ, 機械カプラ }\end{array}$ & $\begin{array}{l}\text { 骨導受話器などの校正に用いる, 機械インピー } \\
\text { ダンスを規定したカプラ。 }\end{array}$ & mechanical coupler & 2159 \\
\hline
\end{tabular}




\begin{tabular}{|c|c|c|c|}
\hline $\begin{array}{l}\text { 用 語 } \\
\text { 読 み 方 }\end{array}$ & 意 & 対応英語 (参考) & 参考 · 補足 \\
\hline ひずみ & $\begin{array}{l}\text { 望ましくない波形の変化。雑音, 及び変調や検 } \\
\text { 波などの結果生じる必要な波形の変化は通常ひ } \\
\text { ずみには含まない。 }\end{array}$ & distortion & $\begin{array}{r}\text { JIS Z8107-1984 } \\
2128\end{array}$ \\
\hline 高調波ひずみ & $\begin{array}{l}\text { 入力量が一つの正弦波であるとき，出力量に高 } \\
\text { 調波成分が発生する非直線ひずみ。 }\end{array}$ & harmonic distortion & 2043 \\
\hline 非直線ひずみ & $\begin{array}{l}\text { 入力量とそれに対応する出力量との間に比例関 } \\
\text { 係がないときに現れるひずみ。 }\end{array}$ & non-linear distortion & 2129 \\
\hline $\begin{array}{l}\text { 波形ひずみ } \\
\text { (はけいひずみ) }\end{array}$ & 波形の変化として現れるひずみ & waveform distortion & 2123 \\
\hline $\begin{array}{l}\text { 過渡Uずみ } \\
\text { (かとひずみ) }\end{array}$ & $\begin{array}{l}\text { 入力量の振幅や周波数が急激に変化するときに } \\
\text { 生じるひずみ。 }\end{array}$ & transient distortion & 2027 \\
\hline 混変調ひずみ & $\begin{array}{l}\text { 入力量が二つ以上の正弦波であるとき，出力量 } \\
\text { にそれらの和又は差の周波数成分が発生する非 } \\
\text { 直線ひずみ }\end{array}$ & $\begin{array}{l}\text { inter-modulation } \\
\text { distortion }\end{array}$ & 2052 \\
\hline フィルタ & $\begin{array}{l}\text { 特定の周波数帯域の信号を通過させ，それ以外 } \\
\text { の周波数の信号を阻止する装置。 }\end{array}$ & (wave) filter & 2131 \\
\hline 通過帯域 & フィルタなどで, 信号が通過する周波数範囲。 & $\begin{array}{l}\text { pass band, } \\
\text { passing band }\end{array}$ & 2106 \\
\hline 隇衰带域 & $\begin{array}{l}\text { フィルタなどで，信号の通過が阻止される周波 } \\
\text { 数範囲。 }\end{array}$ & attenuation band & 2039 \\
\hline 遮断周波数 & $\begin{array}{l}\text { フィルタなどで, 通過帯域と隇衰带域との境界 } \\
\text { の周波数。 }\end{array}$ & cut-off frequency & 2062 \\
\hline 帶 域 幅 & $\begin{array}{l}\text { フィルタなどの通過鱼域の幅。帯域フィルタの } \\
\text { 場合は, 二つの遮断周波数の差又は比(オクタ } \\
\text { ーブ) で表す。 }\end{array}$ & band width & 2099 \\
\hline 呼ひ遮断周波数 & $\begin{array}{l}\text { 平らな通過帯域をもつフィル夕において，その } \\
\text { 感度が通過帯域にお汀る值より3dB 低くなる } \\
\text { 周波数。 }\end{array}$ & $\begin{array}{l}\text { nominal cut-off } \\
\text { frequency }\end{array}$ & 2041 \\
\hline 呼び帯域幅 & 公称遮断周波数で表した带域幅。 & nominal band width & 2042 \\
\hline 高域フィルタ & $\begin{array}{l}\text { 周波数 } f \text { から無限大までを通過帯域とし，零か } \\
\text { ら } f \text { までを減衰帯域とするフィル。 } \\
\text { この場合， } f \text { は零及び無限大を除く任意の值 } \\
\text { とする。 }\end{array}$ & high-pass filter & 2040 \\
\hline 低域フィルタ & $\begin{array}{l}\text { 周波数需から } f \text { までを通過带域とし， } f \text { から無 } \\
\text { 限大までを隇衰帯域とするフィルタ。 } \\
\text { この場合， } f \text { は零及び無限大を除く任意の值 } \\
\text { とする。 }\end{array}$ & low-pass filter & 2107 \\
\hline & · & & \\
\hline
\end{tabular}




\begin{tabular}{|c|c|c|c|}
\hline $\begin{array}{l}\text { 用 語 } \\
\text { 読 み 方 }\end{array}$ & 意 & 対応英語 (参考) & 参考 - 補足 \\
\hline 帯域フィルタ & $\begin{array}{l}\text { 周波数 } f_{1} \text { から } f_{2} \text { までを通過帯域とし, 零から } f_{1} \\
\text { 及び } f_{2} \text { から無限大までを減衰帯域とするフィ } \\
\text { ル夕。 } \\
\quad \text { この場合, } f_{1}, f_{2}\left(f_{2}>f_{1}\right) \text { は, 零及び無限大を } \\
\text { 除く任意の値とする。 }\end{array}$ & band-pass filter & $\begin{array}{r}\text { JIS Z8107-1984 } \\
2100\end{array}$ \\
\hline 帯域消去フィルタ & $\begin{array}{l}\text { 周波数 } f_{1} \text { から } f_{2} \text { までを減衰帯域とし, 零から } f_{1} \\
\text { 及び } f_{2} \text { から無限大までを通過帯域とするフィ } \\
\text { ル夕。 } \\
\quad \text { この場合, } f_{1}, f_{2}\left(f_{2}>f_{1}\right) \text { は, 零及び無限大を } \\
\text { 除く任意の値とする。 }\end{array}$ & $\begin{array}{l}\text { band-stop filter, } \\
\text { band-elimination } \\
\text { filter }\end{array}$ & 2098 \\
\hline 音響フィルタ & 音響系で用いるフィルタ。 & acoustic filter & 2022 \\
\hline 消 音 器 & $\begin{array}{l}\text { 音響フィルタの一種で, 主として騒音の軽減な } \\
\text { どに用いる低域フィルタ。 }\end{array}$ & silencer, muffier & 2070 \\
\hline 音響分析器 & 音響スペクトルを測定する装置。 & $\begin{array}{l}\text { sound analyser, } \\
\text { sound analyzer }\end{array}$ & 2023 \\
\hline $\begin{array}{l}\text { オクターブバンド } \\
\text { 分析器 }\end{array}$ & 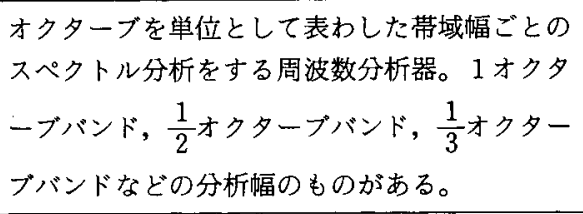 & octave band analyzer & 2012 \\
\hline FFT 分析器 & $\begin{array}{l}\text { 高速フーリエ変換（FFT : Fast Fourier Trans- } \\
\text { form）を用いた周波数分析器。 }\end{array}$ & FFT analyzer & 1010 \\
\hline 变 換 器 & $\begin{array}{l}\text { ある系から入力信号を受けて, これを他の系に } \\
\text { 異なった種類の出力信号として供給し, 入力側 } \\
\text { の信号がもつ必要な特徵が出力側に伝わるよう } \\
\text { にした装置。 }\end{array}$ & transducer & 2140 \\
\hline 電気音響变換器 & $\begin{array}{l}\text { 電気系からの信号によって駆動されて音響系に } \\
\text { 信号を供給し, 又はその逆の動作を行う装置。 }\end{array}$ & $\begin{array}{l}\text { electroacoustic } \\
\text { transducer }\end{array}$ & 2109 \\
\hline 電気機械变換器 & $\begin{array}{l}\text { 電気系からの信号によって駆動されて機械系に } \\
\text { 信号を供給し, 又はその逆の動作を行う装置。 }\end{array}$ & $\begin{array}{l}\text { electromechanical } \\
\text { transducer }\end{array}$ & 2110 \\
\hline 受動変換器 & 出力が入力信号だけによって定まる変換器。 & passive transducer & 2068 \\
\hline マイクロホン & $\begin{array}{l}\text { 音響信号を電気信号に変換する電気音響変換 } \\
\text { 器。 }\end{array}$ & microphone & 2147 \\
\hline 標準マイクロホン & $\begin{array}{l}\text { 音響測定の標準として用いるマイクロホンで, } \\
\text { 規定の構造と特性をもち, 校正された感度が厳 } \\
\text { 密に維持されているもの。 } \\
\text { 備考 JIS C } 5515 \text { (標準コンデンサマイクロホ } \\
\text { ン) に規定してある。 }\end{array}$ & standard microphone & 2130 \\
\hline $\begin{array}{l}\text { プロープマイクロ } \\
\text { ホン }\end{array}$ & $\begin{array}{l}\text { 音場の } 1 \text { 点における音压を, その付近の音場を } \\
\text { あまり乱すことなく測定するマイクロホン。 }\end{array}$ & probe microphone & 2134 \\
\hline
\end{tabular}




\begin{tabular}{|c|c|c|c|}
\hline $\begin{array}{l}\text { 用 語 } \\
\text { 読 み 方 }\end{array}$ & 意 & 対応英語 (参考) & 参考・補足 \\
\hline $\begin{array}{l}\text { いんこう(咽唉)マ } \\
\text { イクロホン }\end{array}$ & $\begin{array}{l}\text { 声帯に近いいんこう (咽唉) 部に接触させて使 } \\
\text { 用するマイクロホン。 }\end{array}$ & throat microphone & $\begin{array}{r}\text { JIS Z8107-1984 } \\
2008\end{array}$ \\
\hline 送 話 器 & $\begin{array}{l}\text { (1) マイクロホンに同じ。 } \\
\text { (2) 電話機に用いるマイクロホン。 }\end{array}$ & $\begin{array}{l}\text { (1) microphone } \\
\text { (2) telephone micro- } \\
\text { phone }\end{array}$ & 2095 \\
\hline スピーカ & $\begin{array}{l}\text { 電気信号を音響信号に変換し, 音波を空間に放 } \\
\text { 射するための電気音響変換器又は変換装置の総 } \\
\text { 称。 }\end{array}$ & loudspeaker & 2080 \\
\hline レベルレコーダ & $\begin{array}{l}\text { 電気信号の振幅をデシベル化し, 記録紙に記録 } \\
\text { する装置。高速度レベルレコーダや指数応答形 } \\
\text { レベルレコーダなど数種類の方式のものがあ } \\
\text { る。 } \\
\text { 備考 騒音レベルや振動レベルの記録を目的と } \\
\text { するJIS C } 1512 \text { (騒音レベル, 振動レベ } \\
\text { ル記録用レベルレコーダ) に規定してあ } \\
\text { る。 }\end{array}$ & level recorder & 2169 \\
\hline 騒音 計 & $\begin{array}{l}\text { 騒音レベルの測定器。 } \\
\text { 備考 JIS C } 1505 \text { (精密騒音計) と JIS C } 1502 \\
\quad \text { （普通騒音計）に規定されている。 }\end{array}$ & sound level meter & 2088 \\
\hline 振 動 計 & 振動体の変位, 速度又は加速度を測定する装置。 & vibration meter & 2075 \\
\hline 振動レベル計 & $\begin{array}{l}\text { 振動感覚補正を行った振動加速度レベルを測定 } \\
\text { する装置。 } \\
\text { 備考 JIS C } 1510 \text { (振動レベル計) に規定してあ } \\
\text { る。 }\end{array}$ & vibration level meter & 2078 \\
\hline $\begin{array}{l}\text { 人エの耳 } \\
\text { (じんこうのみみ) } \\
\text { 擬 似 耳 } \\
\text { (ぎじみみ) }\end{array}$ & $\begin{array}{l}\text { 人間の正常な耳と等価な音響インピーダンスを } \\
\text { もち, 音圧を測定するマイクロホンを備えたイ } \\
\text { ヤホン校正装置。 }\end{array}$ & $\begin{array}{l}\text { artificial ear, } \\
\text { ear simulator }\end{array}$ & 2074 \\
\hline $\begin{array}{l}\text { 人エの乳様突起 } \\
\text { (じんこうのにゅ } \\
\text { うょうとっき) }\end{array}$ & $\begin{array}{l}\text { 人間の正常な乳様突起と等価な機械インピーダ } \\
\text { ンスをもつ骨導受話器校正装置。 }\end{array}$ & $\begin{array}{l}\text { artificial mastoid, } \\
\text { mastoid simulator }\end{array}$ & 2073 \\
\hline $\begin{array}{l}\text { 人エのロ } \\
\text { (じんこうのくち) } \\
\text { 擬 似口 } \\
\text { (ぎじこう) }\end{array}$ & $\begin{array}{l}\text { 人間の正常な口と同様な音場を生じるようにス } \\
\text { ピーカ及びバフルを組み合わせた装置。 }\end{array}$ & $\begin{array}{l}\text { artificial mouth, } \\
\text { mouth simulator }\end{array}$ & 2072 \\
\hline 補 聴 器 & $\begin{array}{l}\text { 聴覚に障害のある人が聴力の低下を補うために } \\
\text { 使用する器具。通常, マイクロホン, 増幅器及 } \\
\text { びイヤホン（又は骨導受話器）を含む。 }\end{array}$ & hearing aid & 2142 \\
\hline & & & \\
\hline
\end{tabular}




\begin{tabular}{|c|c|c|c|}
\hline $\begin{array}{l}\text { 用 語 } \\
\text { 読 み 方 }\end{array}$ & 味 & 対応英語(参考) & - 補足 \\
\hline $\begin{array}{l}\operatorname{CROS}(\text { 型) 補聴器 } \\
\text { (くろす(がた)ほ } \\
\text { ちょうき) }\end{array}$ & $\begin{array}{l}\text { 受話器を装用する耳と反対側の耳の近くにマイ } \\
\text { クロホンがある型式の眼鏡型, 耳かけ型補聴器。 }\end{array}$ & $\begin{array}{l}\text { contralateral routing } \\
\text { of signals } \\
\text { CROS (type) } \\
\text { hearing aid }\end{array}$ & 用 $20,72,1977$ \\
\hline $\begin{array}{l}\text { FROS(型) 補聴器 } \\
\text { (えふろす(がた) } \\
\text { ほちょうき) }\end{array}$ & $\begin{array}{l}\text { マイクロホンの音の取り入れ口が眼鏡のフレー } \\
\text { ムにある型式の眼鏡型補聴器。 }\end{array}$ & $\begin{array}{l}\text { front routing of signals } \\
\text { FROS(type) } \\
\text { hearing aid }\end{array}$ & $20,72,1977$ \\
\hline $\begin{array}{l}\text { IROS(型)補聴器 } \\
\text { (あいろす, また } \\
\text { は,いろす(がた) } \\
\text { ほちょうき) }\end{array}$ & $\begin{array}{l}\text { マイクロホンは装用耳の近くにあるが, 非閉鎖 } \\
\text { 型イヤモールドを使用する型式の眼鏡型, 耳か } \\
\text { け型補聴器 }\end{array}$ & $\begin{array}{l}\text { ipsilateral routing of } \\
\text { signals } \\
\text { IROS (type) } \\
\text { hearing aid }\end{array}$ & 用 $20,72 ， 1977$ \\
\hline イヤモールド & $\begin{array}{l}\text { 外耳道および耳介腔付近の型をとって作製し, } \\
\text { イヤホンの装着固定を容易にしたもの }\end{array}$ & earmold & 用 $20,72,1977$ \\
\hline $\begin{array}{l}\text { 側管っきイヤモー } \\
\text { ルド, ベントっき } \\
\text { イヤモールド }\end{array}$ & $\begin{array}{l}\text { 受話器から装用耳に到達する音の性質を変化さ } \\
\text { せたり, 装用時の圧迫感を軽減する目的で外部 } \\
\text { につながる側管をあけたイヤモールド。 }\end{array}$ & vented earmold & $20,72,1977$ \\
\hline $\begin{array}{l}\text { (外耳道)開放型イ } \\
\text { ヤモールド }\end{array}$ & $\begin{array}{l}\text { 外耳道の入口の大部分を塞がない形式のイヤモ } \\
\text { ールド。 }\end{array}$ & open (canal) earmold & 用 $20,72,1977$ \\
\hline 補聴器の挿入利得 & $\begin{array}{l}\text { 補聴器を装用したときの鼓膜直前の音圧レベル } \\
\text { と補聴器を装用しないときの鼓膜直前の音圧レ } \\
\text { ベルとの差。 } \\
\text { 注 湘定条件によって「実耳挿入利得」「擬似耳 } \\
\text { 挿入利得」なとと呼ばれるので, 単に「挿入 } \\
\text { 利得」の用語を用いるときは測定条件を明記 } \\
\text { する必要がある。 }\end{array}$ & $\begin{array}{l}\text { insertion gain of } \\
\text { hearing aid, } \\
\text { ethymotic gain of } \\
\text { hearing aid }\end{array}$ & 用 $26,90,1983$ \\
\hline 実耳挿入利得 & $\begin{array}{l}\text { 1. 被検者の耳について測定した挿入利得 } \\
\text { 2. 補聴器を装用した被検者の鼓膜直前の音圧 } \\
\text { レベルと補聴器を装用しないときの鼓膜直前 } \\
\text { の音圧レベルとの差 } \\
\text { 注 補聴器を装用したときの音場法による } \\
\text { (MAF 表示の) 最小可聴值と補聴器を装用し } \\
\text { ないときの最小可聴值との差を奉耳挿入利得 } \\
\text { とみなすこともあるが, その場合は測定法を } \\
\text { 明記する必要がある。 }\end{array}$ & $\begin{array}{l}\text { functional insertion } \\
\text { gain, } \\
\text { functional ethymotic } \\
\text { gain }\end{array}$ & 用 $26,90,1983$ \\
\hline $\begin{array}{l}\text { 擬似耳挿入利得 } \\
\text { (ぎじみみそうに } \\
\text { ゆうりとく) }\end{array}$ & $\begin{array}{l}\text { 平均的な人間の模型を用いて測定した挿入利 } \\
\text { 得。 }\end{array}$ & $\begin{array}{l}\text { simulated insertion } \\
\text { gain, } \\
\text { simulated ethymotic } \\
\text { gain }\end{array}$ & 用 $26,90,1983$ \\
\hline 裸耳利得 & $\begin{array}{l}\text { 無響室で被検者（耳に何もつけず，あるいは何 } \\
\text { も挿入しない状態）の鼓膜直前の音圧レベルと， } \\
\text { その位置で被検者を除いた場合の自由音場の音 } \\
\text { 圧レベルとの差。 }\end{array}$ & open ear gain & 用 $26,90,1983$ \\
\hline
\end{tabular}




\begin{tabular}{|c|c|c|c|}
\hline $\begin{array}{c}\text { 用 語 } \\
\text { 読 み 方 }\end{array}$ & \multicolumn{1}{|c|}{ 意 } & \multicolumn{1}{|c|}{ 対応英語(参考) } & 参 考・補 足 \\
\hline 擬似耳利得 & $\begin{array}{l}\text { 平均的人間の模型を用いて測定した裸耳の利 } \\
\text { 得。 }\end{array}$ & $\begin{array}{l}\text { simulated open ear } \\
\text { gain }\end{array}$ & 用 $26,90,1983$ \\
\hline
\end{tabular}

C. 聴 覚

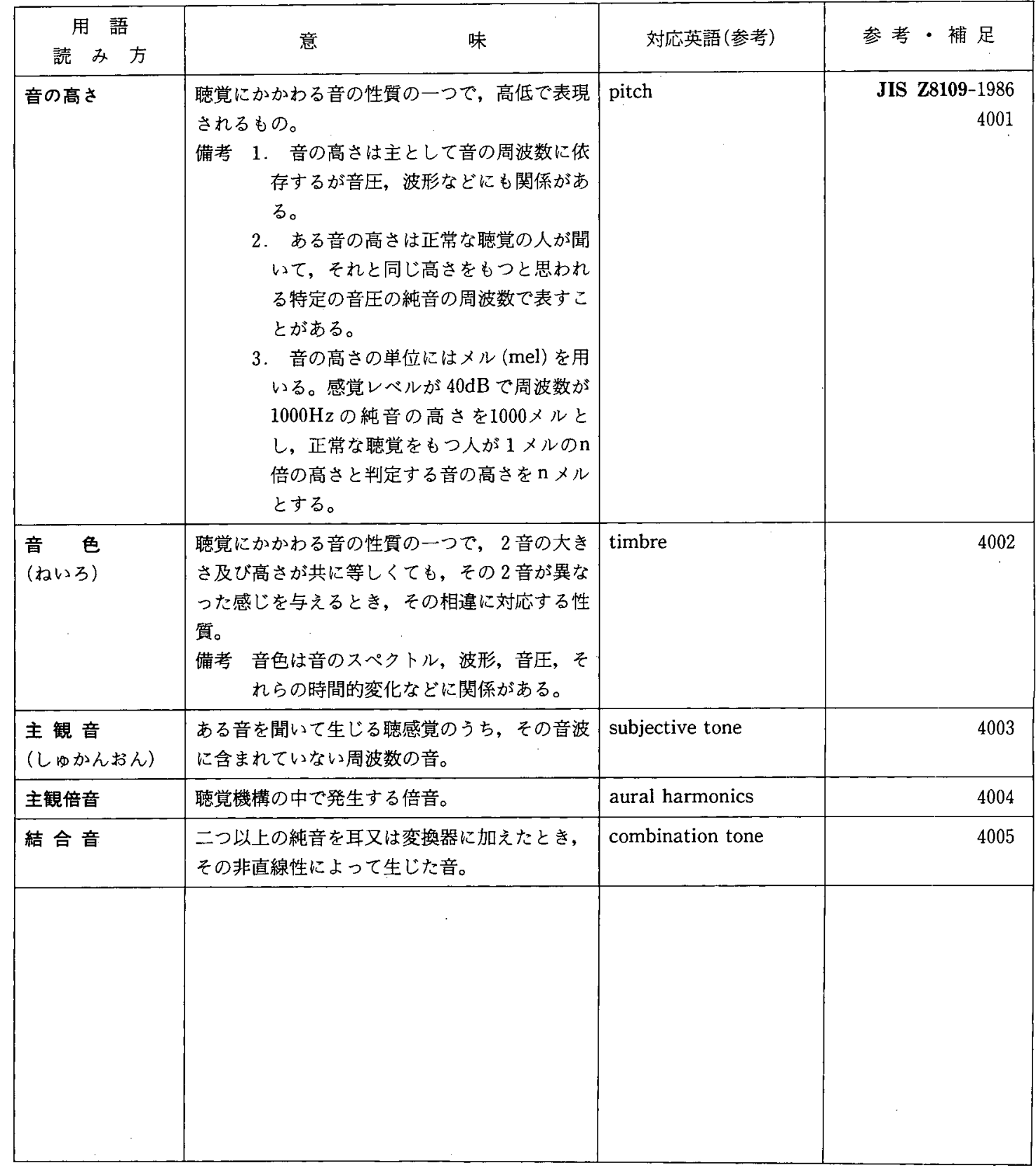




\begin{tabular}{|c|c|c|c|}
\hline $\begin{array}{l}\text { 用 語 } \\
\text { 読 み 方 }\end{array}$ & 意 & 対応英語 (参考) & - 補足 \\
\hline 最小可聴(域)值 & 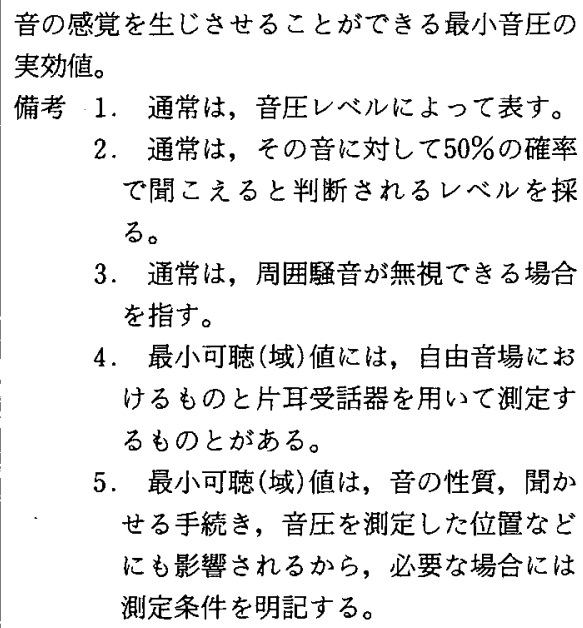 & $\begin{array}{l}\text { (英) threshold } \\
\text { hearing } \\
\text { (米) threshold of } \\
\text { audibility }\end{array}$ & $\begin{array}{r}\text { JIS Z8109-1986 } \\
4006 \\
\text { 「域」は「閥」でも可 }\end{array}$ \\
\hline 最大可聴(域)值 & $\begin{array}{l}\text { 音の感覚以外に他の不快な感覚, 例えば, 痛感 } \\
\text { などを生じさせる音圧の最小の実効値。 } \\
\text { 備考 通常は, 音圧レベルによって表す。 }\end{array}$ & $\begin{array}{l}\text { threshold feeling } \\
\text { (threshold of tickle) }\end{array}$ & $\begin{array}{r}4007 \\
\Gamma \text { 域」は「䦣」でも可 }\end{array}$ \\
\hline 可聴範囲 & $\begin{array}{l}\text { 周波数の関数として表された最小可聴値の曲線 } \\
\text { と最大可聴値の曲線とで囲まれる範囲。 }\end{array}$ & $\begin{array}{l}\text { auditory sensation } \\
\text { area }\end{array}$ & 4008 \\
\hline $\begin{array}{l}\text { 弁 別 域 } \\
\text { (べんべついき) }\end{array}$ & $\begin{array}{l}\text { 感覚で検知できる刺激の最小変化量。 } \\
\text { 備考 通常は } 50 \% \text { 確率で検知できると判断さ } \\
\text { れる最小変化量を採る。 }\end{array}$ & $\begin{array}{l}\text { difference limen; DL } \\
\text { (differential } \\
\text { threshold), } \\
\text { (just noticeable } \\
\text { difference; jnd) }\end{array}$ & 4009 \\
\hline 音の大きさ & 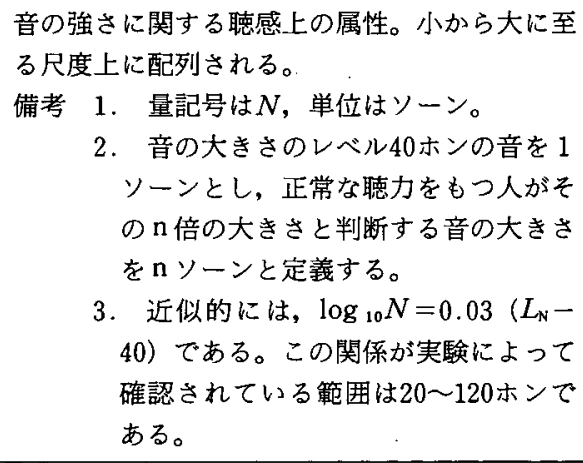 & loudness & $\begin{array}{r}\text { JIS Z8106-1983 } \\
1009\end{array}$ \\
\hline $\begin{array}{l}\text { 音の大ききのレベ } \\
\text { ル }\end{array}$ & $\begin{array}{l}\text { ある音について, 正常な聴力をもつ人が, その } \\
\text { 音と同じ大きさに聞こえると判断した } 1000 \mathrm{~Hz} \\
\text { の純音の音圧レベル。 } \\
\text { 備考 } 1 . \text { 量記号は } L_{\mathrm{N}} \text {, 単位はホン。 } \\
\text { 2. ホンは, 計量法で騒音レベルの単位 } \\
\text { として使われることもあるので注意が } \\
\quad \text { 必要である。 }\end{array}$ & loudness level & 1010 \\
\hline
\end{tabular}




\begin{tabular}{|c|c|c|c|}
\hline $\begin{array}{c}\text { 用 語 } \\
\text { 読 み，方 }\end{array}$ & 味 & 対応英語 (参考) & 参考 - 補足 \\
\hline $\begin{array}{l}\text { 音の大きさの等感 } \\
\text { 曲線 }\end{array}$ & $\begin{array}{l}\text { 等しい大きさに感じる純音の音圧レベルを周波 } \\
\text { 数の関数として示す曲線。 }\end{array}$ & $\begin{array}{l}\text { loudness contour, } \\
\text { equal loudness contour }\end{array}$ & $\begin{array}{r}\text { JIS Z8019-1986 } \\
4010\end{array}$ \\
\hline 感覚レペル & $\begin{array}{l}\text { ある音の音圧レベルがら，その音の最小可聴値 } \\
\text { を差し引いた値。個人あるいは特定集団の最小 } \\
\text { 可聴値上の音のレベル。 }\end{array}$ & $\begin{array}{ll}\text { (英) } & \text { sensation level } \\
\text { (米) level above } \\
\\
\text { threshold, } \\
\\
\text { (sensation level) }\end{array}$ & 4011 \\
\hline 補充現象 & $\begin{array}{l}\text { 弱い音は聞きにくいが，強い音は正常耳と同じ } \\
\text { ような大きさに聞こえる病的現象。 }\end{array}$ & recruitment & 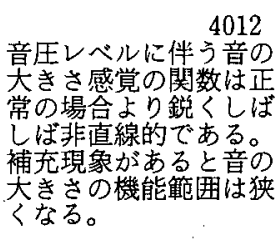 \\
\hline マスキング & 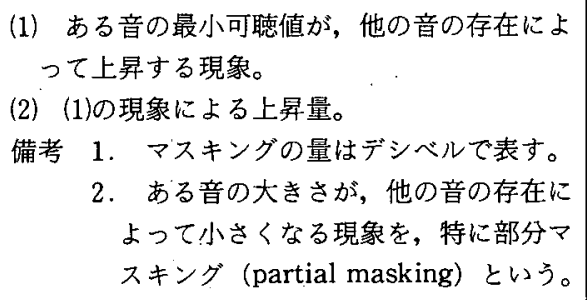 & $\begin{array}{l}\text { masking, } \\
\text { aural masking }\end{array}$ & 4013 \\
\hline $\begin{array}{l}\text { マスキング } \\
\text { オージオグラム }\end{array}$ & $\begin{array}{l}\text { ある音によるマスキング(量, } \mathrm{dB} \text { ) を周波数の } \\
\text { 関数として図示したもの。 }\end{array}$ & masking audiogram & ANSI S3, 20-1973 \\
\hline $\begin{array}{l}\text { 臨界帯域(幅) } \\
\text { (りんかいたいい } \\
\text { きはば) }\end{array}$ & 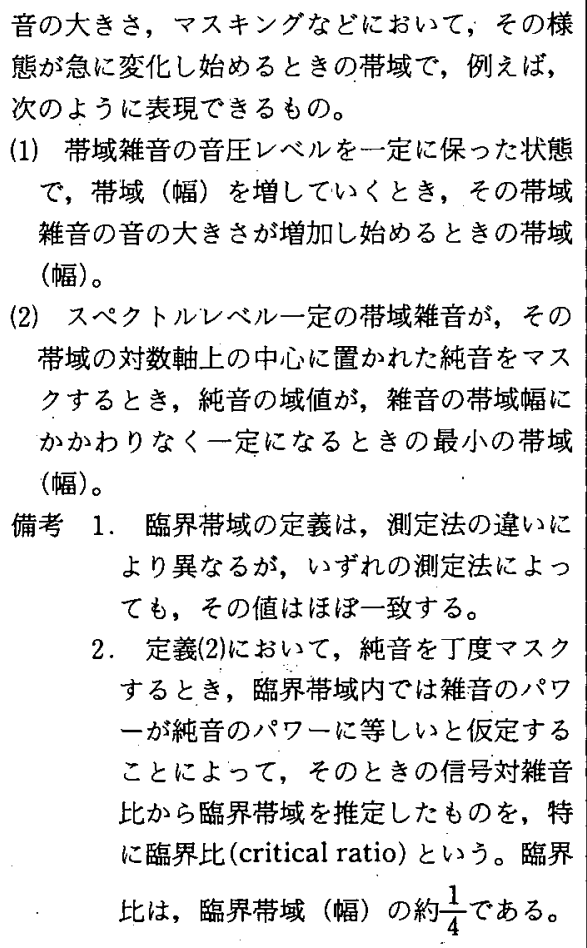 & $\begin{array}{l}\text { critical band, } \\
\text { critical bandwidth }\end{array}$ & $\begin{array}{r}\text { JIS Z8109-1986 } \\
4014\end{array}$ \\
\hline
\end{tabular}




\begin{tabular}{|c|c|c|c|}
\hline $\begin{array}{l}\text { 用 語 } \\
\text { 読 み 方. }\end{array}$ & 意 & 対応英語 (参考) & 参考・補足 \\
\hline $\begin{array}{l}\text { 単 耳 聴（たんじ } \\
\text { ちょう） }\end{array}$ & $\begin{array}{l}\text { 音の刺激が片方の耳だけに与えられるような音 } \\
\text { の聴取状態。 } \\
\text { 備考 片耳聴(かたみみちょう)と呼ばれること } \\
\quad \text { もある。 }\end{array}$ & $\begin{array}{l}\text { monotic hearing, } \\
\text { (monaural hearing) }\end{array}$ & $\begin{array}{r}\text { JIS Z8109-1986 } \\
4015\end{array}$ \\
\hline $\begin{array}{l}\text { 両 耳 聴 } \\
\text { (りょうじちょう) }\end{array}$ & $\begin{array}{l}\text { 音の刺激が両方の耳に与えられるような音の聴 } \\
\text { 取状態。 }\end{array}$ & binaural hearing & 4016 \\
\hline $\begin{array}{r}\text { ダイオティック } \\
\text { ヒアリンク }\end{array}$ & $\begin{array}{l}\text { 両方の耳に与えられる音の刺激が全く等しい両 } \\
\text { 耳聴。 }\end{array}$ & diotic hearing & 4017 \\
\hline $\begin{array}{r}\text { ダイコティック } \\
\text { ヒアリンク }\end{array}$ & $\begin{array}{l}\text { 両方の耳に与えられる音の刺激が異なっている } \\
\text { 両耳聴。 } \\
\text { 備考 音の刺激の異なりには, 周波数の相異, } \\
\text { 振幅の相異, 位相の相異がある。 }\end{array}$ & dichotic hearing & 4018 \\
\hline $\begin{array}{l}\text { 定 位 } \\
(\tau い い)\end{array}$ & $\begin{array}{l}\text { 音場において, 聴覚によって聴取者が感じる距 } \\
\text { 離感と方向感を伴った音源の位置感覚。 } \\
\text { 備考 定位は, 受話器聴取時に感じる頭内定位 } \\
\text { (lateralization) と区別される。 }\end{array}$ & $\begin{array}{l}\text { localization, } \\
\text { auditory localization }\end{array}$ & 4019 \\
\hline オージオメータ & 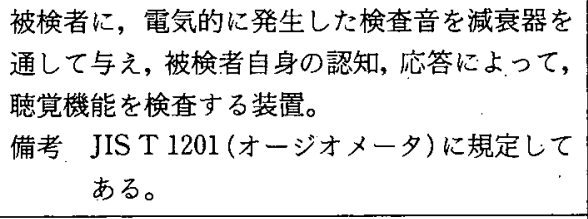 & audiometer & 4020 \\
\hline オージオグラム & 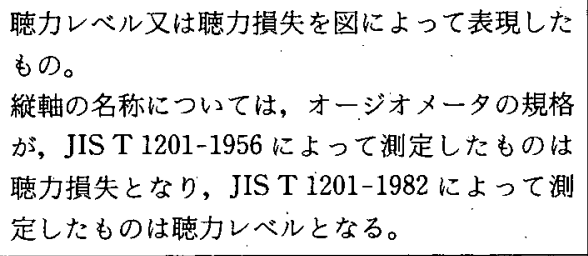 & $\begin{array}{l}\text { audiogram, } \\
\text { (threshold audiogram) }\end{array}$ & 4021 \\
\hline $\begin{array}{l}\text { イミンンオージ } \\
\text { オメータ }\end{array}$ & $\begin{array}{l}\text { 外耳道及び中耳伝音系の音響インピーダンス } \\
\text { (又はアドミタンス) を測定することにようて, } \\
\text { 伝音系の機能を検査する装置。 }\end{array}$ & immitance audiometer & 4022 \\
\hline $\begin{array}{l}\text { 気 導 } \\
\text { (きどう) }\end{array}$ & $\begin{array}{l}\text { 音が外耳道の空気を通して内耳に伝えられるこ } \\
\text { と。 }\end{array}$ & air conduction & 4023 \\
\hline $\begin{array}{l}\text { 骨 } \quad \text { 導 } \\
\text { (こつどう) }\end{array}$ & 音が頭蓋骨を通して内耳へ伝えられること。 & bone conduction & 4024 \\
\hline 気(導)骨導差 & $\begin{array}{l}\text { 気導聴力レベルから骨導聴力レベルを差し引い } \\
\text { た値。 } \\
\text { 備考 聴覚伝音系の損失量を表す。 }\end{array}$ & air bone gap & 4025 \\
\hline
\end{tabular}




\begin{tabular}{|c|c|c|c|}
\hline $\begin{array}{l}\text { 用 語 } \\
\text { 読 み 方 }\end{array}$ & 意 & 対応英語 (参考) & 参考 · 補足 \\
\hline $\begin{array}{l}\text { 域値変化 } \\
\text { (いきちへんか) }\end{array}$ & $\begin{array}{l}\text { ある周波数で最小可聴值が変化すること。 } \\
\text { 備考 1. 変化分が時間の経過とともに少なく } \\
\text { なるときには, 一過性域值変化 (tem- } \\
\text { porary threshold shift) という。 } \\
\text { 2. 変化分が固定して, 減少しないとき } \\
\text { に は永 続性 域 值 変化 (permanent } \\
\text { threshold shift) という。 }\end{array}$ & threshold shift & $\begin{array}{r}\text { JIS Z8109-1986 } \\
4026 \\
\text { 「域」は「闇」でも可 }\end{array}$ \\
\hline $\begin{array}{l}\text { 複 } \quad \text { 聴 } \\
\text { (ふくちょう) }\end{array}$ & $\begin{array}{l}\text { 単一周波数の純音刺激によって二つ以上の音, } \\
\text { 又は雑音として聞こえる, 病的な耳に生じる現 } \\
\text { 象。 }\end{array}$ & diplacusis & 4027 \\
\hline 伝音(性)難聴 & $\begin{array}{l}\text { 外耳・中耳・か(蝸)牛空・前庭空のいずれか, } \\
\text { 又はそのすべてがおかされ，伝送特性が変化す } \\
\text { るために起こる聴覚障害。 }\end{array}$ & conductive hearing loss & 4028 \\
\hline 感音(性)難聴 & $\begin{array}{l}\text { 内耳から皮質聴覍野に至る部位に器質性の障害 } \\
\text { があると考えられる聴覚障害。 }\end{array}$ & & 4029 \\
\hline $\begin{array}{l}\text { 内耳性難聴 } \\
\text { (ないじせいなん } \\
\text { ちょう) }\end{array}$ & $\begin{array}{l}\text { 障害の部位が蝸牛に限局している場合の感音 } \\
\text { (性) 難聴。 }\end{array}$ & inner ear hearing loss & \\
\hline $\begin{array}{l}\text { 後迷路性難聴(こ } \\
\text { うめいろせいなん } \\
\text { ちょう) }\end{array}$ & $\begin{array}{l}\text { 障害の部位が内耳神経から皮質聴覚野を含む区 } \\
\text { 間の聴賞伝導路に限局している場合の感音 (性) } \\
\text { 難聴。 }\end{array}$ & $\begin{array}{l}\text { retrocochlear } \\
\text { hearing loss }\end{array}$ & \\
\hline $\begin{array}{l}\text { 心因性難聴 } \\
\text { (しんいんせいな } \\
\text { んちょう) }\end{array}$ & $\begin{array}{l}\text { きこえの障害のなかで, 器質性のみの障害と考 } \\
\text { えにくい場合のきこえの状態。精神的な原因に } \\
\text { よっておこるきこえの障害, 例えばヒステリー } \\
\text { 性難聴など。 }\end{array}$ & $\begin{array}{l}\text { psychogenic } \\
\text { hearing loss, } \\
\text { nonorganic hearing loss }\end{array}$ & \\
\hline 聴力損失 & 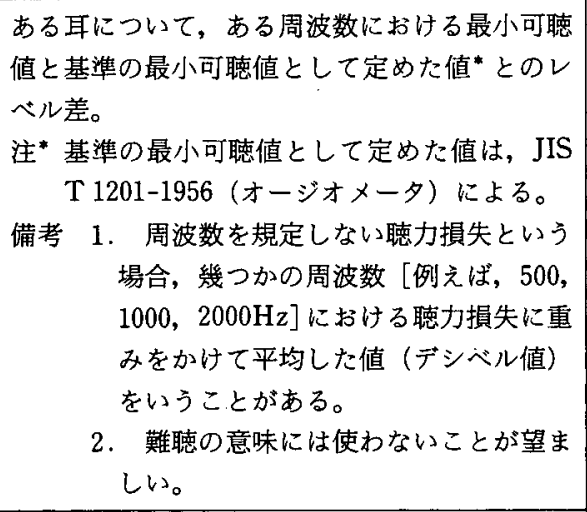 & & 4030 \\
\hline & & & \\
\hline
\end{tabular}




\begin{tabular}{|c|c|c|c|}
\hline $\begin{array}{l}\text { 用 語 } \\
\text { 諒 み 方 }\end{array}$ & 意 & 対応英語 (参考) & 参考 - 補足 \\
\hline 聴カレヘル & 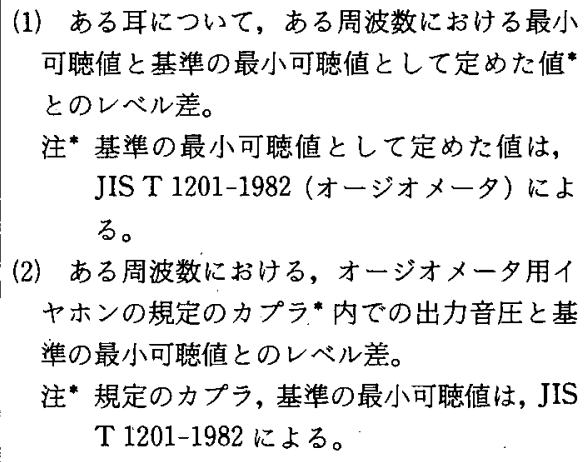 & $\begin{array}{l}\text { (1) hearing threshold } \\
\text { level } \\
\text { (2) hearing level }\end{array}$ & $\begin{array}{r}\text { JIS Z8109-1986 } \\
4031\end{array}$ \\
\hline $\begin{array}{l}\text { 平均聴力損失 } \\
\text { (へいきんちょう } \\
\text { りょくそんしつ) }\end{array}$ & $\begin{array}{l}\text { 周波数 } 500,1000,2000 \mathrm{~Hz} \text { のそれぞれの聴力損 } \\
\text { 失を } \mathrm{a}, \mathrm{b}, \mathrm{c} \text { デシベルとした場合に，(a+2b+ } \\
\mathrm{c} \text { ) } / 4 \text { という式で算出された数值 }(\mathrm{dB}) \text { をいう。 } \\
\text { 備考 国際標準化機構 (ISO) の勧告では（a+ } \\
\text { b+c)/3を用いる。 }\end{array}$ & & \\
\hline 平均聴カレベル & $\begin{array}{l}\text { 周波数 } 500,1000,2000 \mathrm{~Hz} \text { のそれぞれの聴力レ } \\
\text { ベルを } \mathrm{a}, \mathrm{b}, \mathrm{c} \mathrm{dB} \text { とした場合, }(\mathrm{a}+\mathrm{b}+\mathrm{c}) / 3 \\
\text { という式で算出された数值 }(\mathrm{dB}) \text { をいう。 } \\
\text { わが国では }(\mathrm{a}+2 \mathrm{~b}+\mathrm{c}) / 4 \text { が用いられることが } \\
\text { 多い。 }\end{array}$ & & \\
\hline $\begin{array}{l}\text { 詐 聴 } \\
\text { (さちょう) }\end{array}$ & $\begin{array}{l}\text { ある耳できこえの程度を故意に良くまたは悪く } \\
\text { みせかける現象。 }\end{array}$ & $\begin{array}{l}\text { feigning, malingering, } \\
\text { simulation }\end{array}$ & \\
\hline $\begin{array}{l}\text { 騒音の許容基準 } \\
\text { (そうおんのきょ } \\
\text { ようきじゅん) }\end{array}$ & $\begin{array}{l}\text { 1. 騒音環境下で, ほとんどすべての作業者が } \\
\text { 長年月その作業を遂行しても認むべき健康障 } \\
\text { 害をきたさないような騒音の限度をいう。 } \\
\text { 2. 騒音環境下で長年月生活をしていても認む } \\
\text { べき社会生活上の障害をきたさないような騒を } \\
\text { 音の限度をいう。社会生活の条件, たとえば } \\
\text { 会話, 通話, 職業の種類, 就眠など生活状態 } \\
\text { のちがいによりそれぞれ騒音のうるささの限 } \\
\text { 度も異なる。 }\end{array}$ & damage-risk criteria & \\
\hline $\begin{array}{l}\text { 評価騒音レベル } \\
\text { (ひょうかそうお } \\
\text { んれべる) }\end{array}$ & $\begin{array}{l}\text { 騒音レベル〔(dB) }(\mathrm{A})] \text { の值に騒音の特性（ピ } \\
\text { ークファクタ, スペクトル, 持続時間) に応じ } \\
\text { た補正值*を加えた値。 } \\
\text { 注* ISO R 1966-1971 参照のこと。 }\end{array}$ & rating sound level & \\
\hline 1 & $\begin{array}{l}\text { 音のやかましさの感じを表す単位。910 } \\
\text { 〜 1090Hz バンドの } 40 \mathrm{~dB} \text { SPLの音が耳に感ず } \\
\text { るやかましさの程度を1Noyとした。(ISO } \\
\text { R507-1970) }\end{array}$ & Noy, & \\
\hline & & & \\
\hline
\end{tabular}




\begin{tabular}{|c|c|c|c|}
\hline $\begin{array}{l}\text { 用 語 } \\
\text { 読 み 方 }\end{array}$ & 意 & 対応英語 (参考) & 参考 - 補足 \\
\hline $\mathrm{c}^{5}$ ディップ & $\begin{array}{l}4000 \mathrm{~Hz}\left(\mathrm{c}^{5}\right) . \text { を中心としたV 型の切れ込みを示 } \\
\text { すオージオグラム。音響性障害の軽度なものに } \\
\text { みられることが多い。 }\end{array}$ & $c^{5} \operatorname{dip}$ & 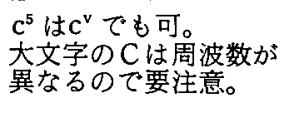 \\
\hline 語音聴カレベル & $\begin{array}{l}57 \text { 語表による検査用レコードあるいは磁気録音 } \\
\text { テープ又は } 67 \text { 語表による検查用磁気録音テープ } \\
\text { を使用して行う語音検査の試験用音声の音量を } \\
\text { 示すレベル。 } \\
\text { 注 検查用レコード又はテーブに録音された } \\
1000 \mathrm{~Hz} \text { 音の周波数レコードを検查前に再生 } \\
\text { し, その出力を VU 計 (JISC } 1102) \text { などで規 } \\
\text { 定の目盛に調整して使用すると, オージオメ } \\
\text {-タの } 1000 \mathrm{~Hz} \text { 音の聴力レベル目盛とその出 } \\
\text { カが等しくなるようにできている。アメリカ } \\
\text { などと違っているので注意。 }\end{array}$ & & \\
\hline $\begin{array}{l}57 \text { 語 表 } \\
\text { (ごうななごひょ } \\
\text { う) }\end{array}$ & $\begin{array}{l}\text { 日本オージオロジー学会で，1957年に定めた数 } \\
\text { 字語表および日本語単音節50語よりなる語音検 } \\
\text { 查用語表。 }\end{array}$ & & \\
\hline $\begin{array}{l}67 \text { 語 表 } \\
\text { (ろくななごひょ } \\
\text { う) }\end{array}$ & $\begin{array}{l}\text { 日本オージオロジー学会で，1967年に定めた数 } \\
\text { 字語表および日本語単音節20語よりなる語音検 } \\
\text { 查用語表。 }\end{array}$ & & \\
\hline $\begin{array}{l}\text { 語音聴取域值 } \\
\text { (ごおんちょうし } \\
\text { ゆいきち) }\end{array}$ & $\begin{array}{l}57 \text { 又は } 67 \text { 語表の数字吾表を用いて, 語音聴力 } \\
\text { を測定し, 単語了解度が } 50 \% \text { に達する語音検査 } \\
\text { のレベルをいう。 }\end{array}$ & $\begin{array}{l}\text { speech reception } \\
\text { threshold; SRT }\end{array}$ & 「域」は「闎」でも可。 \\
\hline $\begin{array}{l}\text { 語音弁別能 } \\
\text { (ごおんべんべつ } \\
\text { のう) }\end{array}$ & $\begin{array}{l}\text { 57又は } 67 \text { 語表の日本語単音節語表を用いて音節 } \\
\text { 明りょう度を測定し，えられたもっとも大きい } \\
\text { 值 }(\%) \text { そいう。 }\end{array}$ & $\begin{array}{l}\text { maximum discrimina- } \\
\text { tion score }\end{array}$ & \\
\hline $\begin{array}{l}\text { スピーチオージオ } \\
\text { グラム }\end{array}$ & $\begin{array}{l}\text { 語音聴取域値と語音弁別能力を図で表現したも } \\
\text { の。 }\end{array}$ & $\begin{array}{l}\text { articulation function, } \\
\text { speech audiogram }\end{array}$ & \\
\hline 有声音 & $\begin{array}{l}\text { 声帯振動を伴う音声音。 } \\
\text { 備考 声帯の周期的振動による脈流を主なエネ } \\
\text { ルギー源（音源).とするので，周期的な } \\
\text { 波形として観察される。 }\end{array}$ & voiced sound & $\begin{array}{r}\text { JIS Z8109-1986 } \\
5001\end{array}$ \\
\hline 無声音 & $\begin{array}{l}\text { 声带振動を伴わない音声音。 } \\
\text { 備考 無声音のエネルギー源は, 声道の狭めで } \\
\text { 生じる乱流（摩擦音など）声道閉鎖の開 } \\
\text { 放によって急速に立ち上がる気流（破裂 } \\
\text { 音など）など。 }\end{array}$ & unvoiced sound & 5002 \\
\hline ホルマント & $\begin{array}{l}\text { 音響管等の伝達関数の極に対応するスペクトル } \\
\text { のエネルギー密集部分（スペクトル包絡の山)。 } \\
\text { 備考 音声では声道を音響管とみなす。 }\end{array}$ & formant & 5004 \\
\hline
\end{tabular}




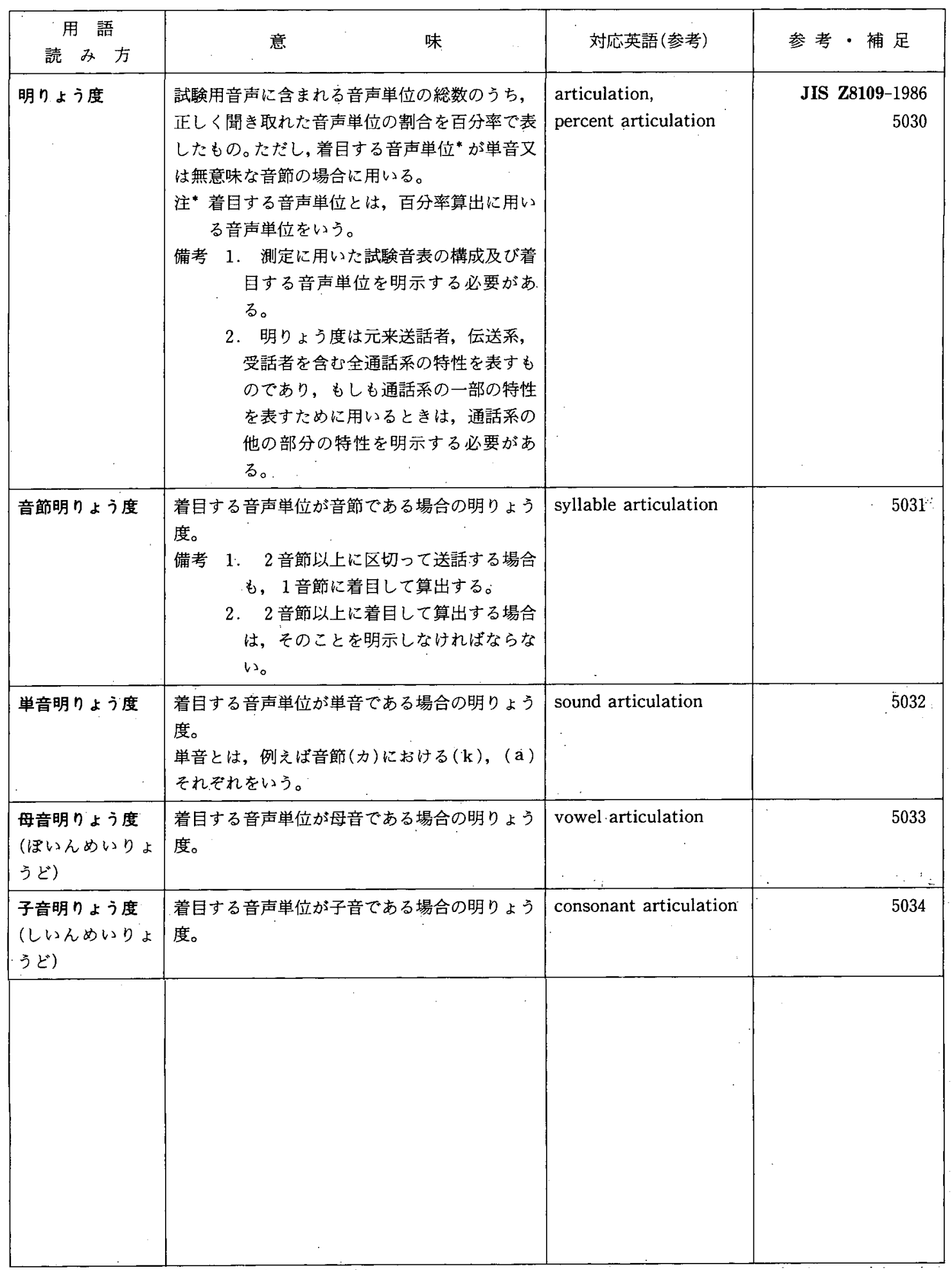




\begin{tabular}{|c|c|c|c|}
\hline $\begin{array}{l}\text { 用 語 } \\
\text { 読 み 方 }\end{array}$ & 味 & 対応英語 (参考) & 参考・補足 \\
\hline 了解度 & $\begin{array}{l}\text { 試験用音声中の着目する単位の総数のうち, 正 } \\
\text { しく聞き取れた単位の割合を百分率で表したも } \\
\text { の。ただし, 着目する音声単位が有意味な単語 } \\
\text { 又は文章の場合に用いる。 } \\
\text { 備考 1. 測定に用いた試験音表の構成及び着 } \\
\text { 目する音声単位を明示する必要があ } \\
\text { る。 } \\
2 \text { 了。解度は, 送話者, 伝送系, 受話者 } \\
\text { を含む全通話系の特性を表すものであ } \\
\text { り, もしも通話系の一部の特性を表す } \\
\text { ために用いるときには, 通話系の他の } \\
\text { 部分の特性を明示する必要がある。 }\end{array}$ & $\begin{array}{l}\text { intelligibility, } \\
\text { percent intelligibility }\end{array}$ & $\begin{array}{r}\text { JIS Z8109-1986 } \\
5038\end{array}$ \\
\hline 単語了解度 & 着目する音声単位が単語である場合の了解度。 & word intelligibility & 5039 \\
\hline 文章了解度 & 着目する単位が文章である場合の了解度。 & sentence intelligibility & 5040 \\
\hline 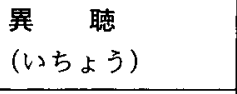 & $\begin{array}{l}\text { 試験用音声中の音声単位が異なった音声単位と } \\
\text { して聴取されること。 }\end{array}$ & $\begin{array}{l}\text { confusion in phoneme } \\
\text { perception }\end{array}$ & 5041 \\
\hline オクターブ & $\begin{array}{l}\text { 周波数比 } 2 \text { の音程。 } \\
\text { 備考 } 1 \text { オクターブの音程をもった二つの音の } \\
\text { 間に含まれるいろいろな音程の音をひと } \\
\text { まとめにしていうこともある。例えば, } \\
\text { 1 点音のオクターブ。 }\end{array}$ & octave & 6006 \\
\hline 聴性誘発反応検査 & $\begin{array}{l}\text { 音刺激によって主として頭部から得られる微小 } \\
\text { な電位変動を加算平均して聴覚検査に利用する } \\
\text { 検查。 } \\
\text { 注 一般的には electric response application; } \\
\text { ERA として聴覚のみならず広い意味に用 } \\
\text { いられる。 }\end{array}$ & $\begin{array}{l}\text { evoked response } \\
\text { audiometry; } \\
\text { ERA }\end{array}$ & \\
\hline 蝸 電 図 & $\begin{array}{l}\text { 鼓室岬又はこれに近い部位の電極（近位電極） } \\
\text { と耳垂や乳突部の電極（遠位電極）との間で誘 } \\
\text { 導される加算反応電位を刺激音の強さの関数と } \\
\text { して表わした波形記録。通常蝸牛マイクロホン } \\
\text { 電位 (CM), 加重電位 (SP), 聴神経複合活動 } \\
\text { 電位 (AP) が含まれる。 }\end{array}$ & $\begin{array}{l}\text { electrocochleogram; } \\
\text { ECochG }\end{array}$ & \\
\hline $\begin{array}{l}\text { 蝸牛マイクロホン } \\
\text { 電位 }\end{array}$ & $\begin{array}{l}\text { 蝸牛有毛細胞に起源をもつ刺激と同じ波形の反 } \\
\text { 応電位。 }\end{array}$ & $\begin{array}{l}\text { cochlear microphonics; } \\
\mathrm{CM}\end{array}$ & \\
\hline 加重電位 & $\begin{array}{l}\text { 刺激音に応じて蝸牛内に発生する刺激時間中継 } \\
\text { 続する直流電位。刺激条件や生体条件や電極部 } \\
\text { 位によって極性が変化する。 }\end{array}$ & $\begin{array}{l}\text { summating potential ; } \\
\text { SP }\end{array}$ & \\
\hline & . & & \\
\hline
\end{tabular}




\begin{tabular}{|c|c|c|c|}
\hline $\begin{array}{l}\text { 用 語 } \\
\text { 読 み 方 }\end{array}$ & 味 & 対応英語 (参考) & 参考 - 補足 \\
\hline $\begin{array}{l}\text { 聴神経複合活動電 } \\
\text { 位 }\end{array}$ & $\begin{array}{l}\text { 蝸牛又はこれに近い部位においた電極で一括記 } \\
\text { 録した多数の蝸牛神経の同時発火による活動電 } \\
\text { 位。 } \\
\text { 一般的に, 活動電位とは主に神経, 筋などにお } \\
\text { いて休止状態にある部分の電位を基準として測 } \\
\text { った興舊状態にある部分の電位変動。䗲状の鋭 } \\
\text { い波形を示す。 }\end{array}$ & $\begin{array}{l}\text { compound action } \\
\text { potenial; } \\
\text { whole nerve } \\
\text { action potential } \\
\text { AP }\end{array}$ & \\
\hline 聴性脳幹反応 & $\begin{array}{l}\text { 音刺激によって頭皮上から得られる一連の聴性 } \\
\text { 電位変動のうち潜時の短い反応。 } \\
\text { 一般に頭丁頁一耳介 (乳突部) 誘導により加算法 } \\
\text { を用いて記録される。本反応は速波成分と呼ば } \\
\text { れる } 5 \sim 7 \text { 個の陽性ピークと速波成分が乗って } \\
\text { いる緩徐成分とからなる。ピーク潜時は } 10 \mathrm{~ms} \\
\text { 以内で主に聴神経並びに脳幹部の聴覚路に起源 } \\
\text { を有する。 }\end{array}$ & $\begin{array}{l}\text { auditory brainstem } \\
\text { response } \\
\text { ABR }\end{array}$ & \\
\hline 聴性中間潜時反応 & $\begin{array}{l}\text { 音刺激によって頭皮上から得られる一連の聴性 } \\
\text { 電位変動のうち脳幹反応より長い潜時 (10 } \\
\text { ～50ms) をもって出現する反応。高位聴覚路と } \\
\text { 関係があるといわれる。 }\end{array}$ & $\begin{array}{l}\text { auditory middle } \\
\text { latency response; } \\
\text { MLR }\end{array}$ & \\
\hline 頭頂部緩反応 & $\begin{array}{l}\text { 音刺激によって頭皮上から得られる一連の聴性 } \\
\text { 電位変動のうち中間潜時反応より長い潜時 ( } 50 \\
\text { 〜 } 500 \mathrm{~ms}) \text { をって出現する反応。脳幹網様体な } \\
\text { ど非特異的広範投射系と関係のある反応といわ } \\
\text { れる。 }\end{array}$ & $\begin{array}{l}\text { slow vertex response; } \\
\text { SVR }\end{array}$ & \\
\hline 期待陰性波 & $\begin{array}{l}\text { 二つの感覚刺激 } \mathrm{S}_{1} \text { 及び } \mathrm{S}_{2} \text { を一定間隔で呈示 } \\
\text { し, } \mathrm{S}_{1} \text { に関連した } \mathrm{S}_{2} \text { としてれを知覚判断し, } \\
\text { 又は運動開始を命じると,この } \mathrm{S}_{1}-\mathrm{S}_{2} \text { の時間間 } \\
\text { 隔に発生する緩徐な一相性の陰性電位変動。 } \\
\mathrm{S}_{1} \text { をwarning stimulus, } \mathrm{S}_{2} \text { を imperative stim- } \\
\text { ulus と呼ぶ。 }\end{array}$ & $\begin{array}{l}\text { contingent negative } \\
\text { variation; } \\
\text { CNV }\end{array}$ & \\
\hline 加算平均 & $\begin{array}{l}\text { 自発放電をはじめ不規則な電位変動や装置から } \\
\text { の雑音に埋まって, そのままでは検出不能な一 } \\
\text { 定潜時の微小反応を刺激開始時刻を基点として } \\
\text { 多数回加算して反心を応検出する信号処理方法。 } \\
\mathrm{n} \text { 回の加算により SN 比は } \sqrt{\mathrm{n}} \text { 倍改善される。 } \\
\text { 平均加算と呼ばれることもある。 }\end{array}$ & averaging & \\
\hline クリック & 持続時間が極めて短い非周期的な音。 & click & \\
\hline トーンバースト & $\begin{array}{l}\text { 波形の始まりと終りに傾斜（立ち上がり時間， } \\
\text { 立ち下がり時間)ををち，その間に定常振幅部 } \\
\text { 分 (プラトー)がある持続時間の短い純音。 }\end{array}$ & tone burst & \\
\hline
\end{tabular}




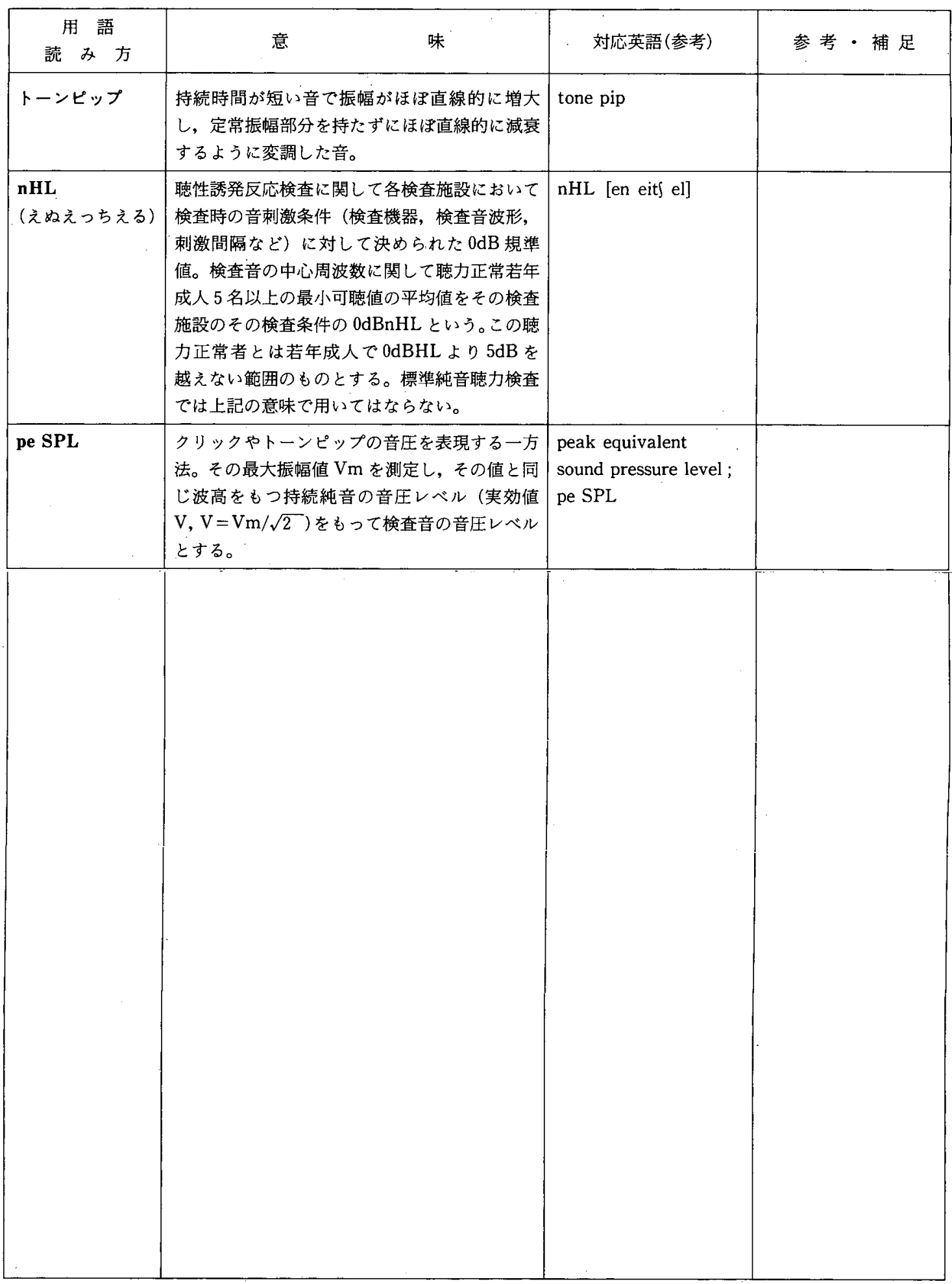




\section{用語索引（アイウエオ順）}

あ

IROS (型) 補聴器（あいろす，または， いろす(がた)はちょうき

暗騥音( あんそうおん)

(

域值変化(いきちへんか)

位 相

位 相 差

異 聴(いちょう)

イミタンスオージオメータ

イヤホン

イヤホンカプラ

イヤプロテクタ

イャモールド

いんこう（咽搌）マイクロホン

う

うなり

z

nHL (えぬえつちえる)

FFT 分析器

FROS(型) 補聴器（えふろす(がた）

$$
\text { はちょうき }
$$

お

オージオグラム

オージオメータ

オクターブ

オクターブバンド分析器

音(おと)

音の大きさ

音の大きさの等感曲線

音の大きさのレべル

音のスペクトル
音の高さ

C-1

音の強さ

A-2

音の強さのレベル

A -2

A-6 音 E(おんあつ)

A-2

音匠スペクトルレベル

A -3

C-5 音王レベル

A-3

A-3 音 響(おんきょう)

A-1

A-3 音響イミタンス

A-6

C-9 音響インピーダンス

A-6

$\mathrm{C}-4$

音響カプラ

B-1

B-1

音 響 学

A-1

B-1

音䈉コンプライアンス

A-6

B-1

音響スチフネス

A -6

B-5

音響スペクトル

A-3

B-4

音響抵抗

A-6

音響フィルタ

B-3

A-4

音響分析器

B-3

音響リアクタンス

A-6

C-11

音さ(叉) (おんさ)

B-1

B-3 音節明り上う度

C -8

B -5

音場（おんじェう）

A-6

音波

A-1

か

C-4 加算平均

C -10

C -4 可聴周波数

A-1

C. -9

可聴範囲

C -2

B -3

過渡ひずみ（かとひずみ）

B-2

A-1

蝸牛マイクロホン電位

C -9

C -2

加重電位

C -9

$\mathrm{C} \div 3$

蝸電図

C -9

C -2

カプラ

B-1

A-3（外耳道）開放型イヤモールド 


\begin{tabular}{|c|c|c|c|}
\hline 感音 (性) 難聴 & $C-5$ & 骨導受話器（とつどうじわき） & $B-1$ \\
\hline 感覚レベル & $\mathrm{C}-3$ & 混変調ひずみ & $\mathrm{B}-2$ \\
\hline き & & さ & \\
\hline 機械カプラ & B-1 & サイクル & $A-1$ \\
\hline 擬似口（ぎしとう） & B-4 & 最小可聴（域）値 & $\mathrm{C}-2$ \\
\hline 擬似耳（きじみみ） & B-4 & 最大可聴（域）值 & $\mathrm{C}-2$ \\
\hline 擬似耳利得 & $B-6$ & 詐聴（さちょう） & $\mathrm{C}-6$ \\
\hline \multicolumn{2}{|c|}{ 擬似耳挿入利得（きざみみそうにゅうりとく）B-5 } & 雑 音 & $A-5$ \\
\hline 期待陰性波 & $\mathrm{C}-10$ & サブハーモニック & $A-4$ \\
\hline 気 導（きどう） & $C-4$ & 残 響 & $A-5$ \\
\hline 気（導）骨導差 & $\mathrm{C}-4$ & 残響時間 & $A-5$ \\
\hline 基本音（きはんおん） & $A-3$ & し & \\
\hline 基本周波数 & $A-4$ & $c^{5}$ デイップ & $\mathrm{C}-7$ \\
\hline 共 振 & $A-4$ & 子音明り上う度（しいんめいりょうど） & $\mathrm{C}-8$ \\
\hline 共振周波数 & A-4 & 実耳挿入利得 & $\mathrm{B}-5$ \\
\hline 共 鳴 & $A-4$ & 遮断周波数 & $\mathrm{B}-2$ \\
\hline 共鳴周波数 & $A-4$ & 自由音場（ビゅうおんじ上う） & A-7 \\
\hline 共鳴振動数 & $A-4$ & 主観音（しゅかんおん） & $\mathrm{C}-1$ \\
\hline$<$ & & 主観倍音 & $\mathrm{C}-1$ \\
\hline CROS(型)補聴器（くろす(がた）ほちようき & $\mathrm{B}-5$ & 周 期 & $A-1$ \\
\hline クリック & $\mathrm{C}-10$ & 周 期 的 & $A-1$ \\
\hline け & & 受動変換器 & $\mathrm{B}-3$ \\
\hline 結 合 音 & $\mathrm{C}-1$ & 周 波 数 & A-1 \\
\hline 减衰帯域 & $\mathrm{B}-2$ & 受話 器 & $B-1$ \\
\hline$こ$ & & 純 音（ビゅんおん） & $A-3$ \\
\hline 高域フィルタ & $\mathrm{B}-2$ & 消 音 器 & $B-3$ \\
\hline 高調. 波 & $A-4$ & 上音（じ上うおん） & $A-4$ \\
\hline 高調波ひずみ & $\mathrm{B}-2$ & 心因性難聴（しんいんせいなんちょう） & $C-5$ \\
\hline 57 語表（ごうななでひょう） & $\mathrm{C}-7$ & 震音（しんおん） & $A-5$ \\
\hline 後迷路性難聴（こうめいろせいなんちょう & $C-5$ & 人エのロ（じんとうのくち） & $B-4$ \\
\hline 語音聴取域值（でおんちょうしゅいきち） & $C-7$ & 人エの乳様突起（しんとうのにゅうようと & き) $\mathrm{B}-4$ \\
\hline 語音聴カレベル & $C-7$ & 人エの耳（しんとうのみみ） & B-4 \\
\hline 語音弁別能（でおんべんべつのう） & $C-7$ & 振 動 & $A-6$ \\
\hline 骨 導( こっどう) & $C-4$ & 振動計 & B-4 \\
\hline
\end{tabular}


振 動 数

振動レベル

振動レベル計

振 幅

ఫ

スピーカ

スピーチオージオグラム

そ

騷 音

䮜音計

A -5

B -4

騥音の許容基準（そうおんのきょようきじゅん） C-6

騒音レベル

侧管つきイャモールド

A -5

聥入イヤホン

B -5

B-1

送話器

B -4

た

帯域幅

B-2

帯域雑音

A -5

帯域消去フィルタ

B-3

帯域フィルタ

B-3

ダィオティックヒアリング

C -4

ダイコティックヒアリング

C -4

単音明り上う度

$\mathrm{C}-8$

単語了解度

C -9

単耳聴（たんじちょう）

C -4

弹性波

A-1

5

超音波(ち上うおんぱ)

聼神経複合活動電位

A -1

C -10

聴性中間潜時反応

C -10

聴性脳幹反応

C -10

聴性誘発反応検查

C -9

超低周波数

調波（ちェうは）
㯖力損失

C -5

聴力レベル

C -6

調和成分

A-4

2

通過寡域

B-2

$\tau$

定位(ていい)

C -4

低域フィルタ

B -2

定在波（ていざいは）

A - 4

定常波（ていじ上うは)

A-5

低調波

A-4

デシベル

A-2

层音（性）難聴

C -5

電気音響変換器

B-3

電気機械変換器

B-3

と

等価䭷音レベル

A-6

頭頂部楥反応

C -10

トーンバースト

C -10

トーンピップ

C -11

ドプラ効果

A -5

な

内耳性難聴（ないじせいなんちょう）

$\mathrm{C}-5$

ね

音色（ねいろ）

$\mathrm{C}-1$

$\infty$

C -6

は

倍音品 $\mathrm{A}$-4

白色雑音（はくしょくざつおん） A-5

波形ひずみ（はけいひずみ） $\quad \mathrm{B}-2$

波 長

A -2

パスカル

A-3

パンド音王レベル 
ひ

pe SPL

C -11

非直線ひずみ

ピストンホン

ひずみ

B-2

評価馶音レベル（ひ上うかそうおんれべる）

標準マイクロホン

ピンクノイズ

ふ

プルタ

B-2

複合音

A-3

複合波

複聴（ふくち上う）

A-3

C -5

部分音

プローブマィクロホン

A -3

B-3

文章了解度

C -9

分数調波

A-4

平均聴力損失（へいきんち上うり上くそんしつ）

平均聼力レベル

ヘッドホン

ヘルッ

変 換 器

ベントつきイヤモールド

弁別域（べんべついき）

ほ

母音明り上う度(ぱいんめいり上うど)

防音保護具

C -6

B-1

A-1

B-3

B-5

$\mathrm{C}-2$

C -6

補充現象

補聴器

補聴器の挿入利得

ホルマント

ま

マイクロパール

C -8

B-1

$\mathrm{C}-3$

B-4

B-5

$\mathrm{C}-7$
マイクロホン

B-3

マスキング

C -3

マスキングオージオグラム

C -3

み

耳覆いイヤホン（みみおわいいやはん）

B-1

耳載せイャホン（みみのせいやはん）

B-1

む

無声音

C-7

め

明り上う度

C -8

メカニカルカフ

B-1

$\Phi$

有声音

C-7

よ

呼び遮断周波数

B-2

呼び帯域幅

B-2

5

裸耳利得

B-5

り

了解度

C -9

両耳聴（りェうじちェう）

C -4

臨界帯域(幅)（りんかいたいいきはば）

C -3

れ

レペルレコーダ

B-4

3

67 語表（ろくななでひ上う）
C-7 


\section{英語索引（A B C 順）}

A

\section{$\mathrm{ABR}$}

acoustic compliance

acoustic coupler

acoustic filter

acoustic immitance

acoustic impedance

acoustic reactance

acoustic resistance

acoustics

acoustic stiffness

air bone gap

air conduction

amplitude

AP

articulation

articulation function

artificial ear

artificial mastoid

artificial mouth

attenuation band

audio frequency

audiogram

audiometer

auditory brainstem response $\mathrm{C}-10$

auditory localization

C -4

auditory middle latency response

auditory sensation area

aural harmonics

C -10

A-6

B-1

B-3

A-6

A-6

A-6

A-1

A-6

$\mathrm{C}-4$

C -4

A-2

C -10

$\mathrm{C}-8$

$\mathrm{C}-7$

B-4

B -4

B-4

B -2

A-1

$\mathrm{C}-4$

$\mathrm{C}-4$

C -10

C -2

$\mathrm{C}-1$
A-6 background noise
A-6

aural masking

averaging

C -10

A-weighted sound pressure

A -5 level

$\mathrm{B}-3$

B-3

A -5

A -3

B-3

B-2

band width

A-4

beats

C -4

binaural hearing

C -4

bone conduction

B-1

bone (conduction) vibrator 
$\begin{array}{lc}\begin{array}{c}\text { confusion in phoneme } \\ \text { perception }\end{array} & \mathrm{C}-9 \\ \text { consonant articulation } & \mathrm{C}-8 \\ \text { contingent negative } & \mathrm{C}-10 \\ \text { variation } & \\ \begin{array}{c}\text { contralateral routing of } \\ \text { signals CROS (type) } \\ \text { hearing aid }\end{array} & \mathrm{B}-5 \\ \begin{array}{l}\text { coupler } \\ \text { critical band } \\ \text { critical bandwidth }\end{array} & \mathrm{B}-1 \\ \text { cut-off frequency } & \mathrm{C}-3 \\ \text { c }^{5} \text { dip } & \mathrm{C}-3 \\ \text { cycle } & \mathrm{B}-2 \\ & \mathrm{C}-7\end{array}$

C-9 ear protector

B-1

ear simulator

B-4

ECochG

C-9

elastic wave

A-1

electroacoustic transducer B-3

electrocochleogram

C -9

electromechanical transducer B-3 equal loudness contour

C -3

equivalent continuous Aweighted sound pressure level

ERA

C -9

ethymotic gain of hearing aid

evoked response audiometry

C -9

D

\section{F}

damage-risk criteria

C -6

$\mathrm{dB}$

A-2

feigning

C -6

A-2

FFT analyzer

B-3

decibel

C- -4

filter

B-2

dichotic hearing

C-2

formant

C -7

difference limen

C -2

free (sound) field

A-7

differential threshold

C -4

frequency

A-1

diotic hearing

front routing of signals

C -5

FROS (type) hearing aid

B -5

diplacusis

B-2

distortion

C -2

DL

A-5

functional ethymotic gain

B -5

functional insertion gain

B-5

Doppler effect

fundamental

A -3

fundamental frequency

A-3

E

H

earmold

B-5

earphone

B-1

harmonic

A-4

earphone coupler

harmonic component

A-4 


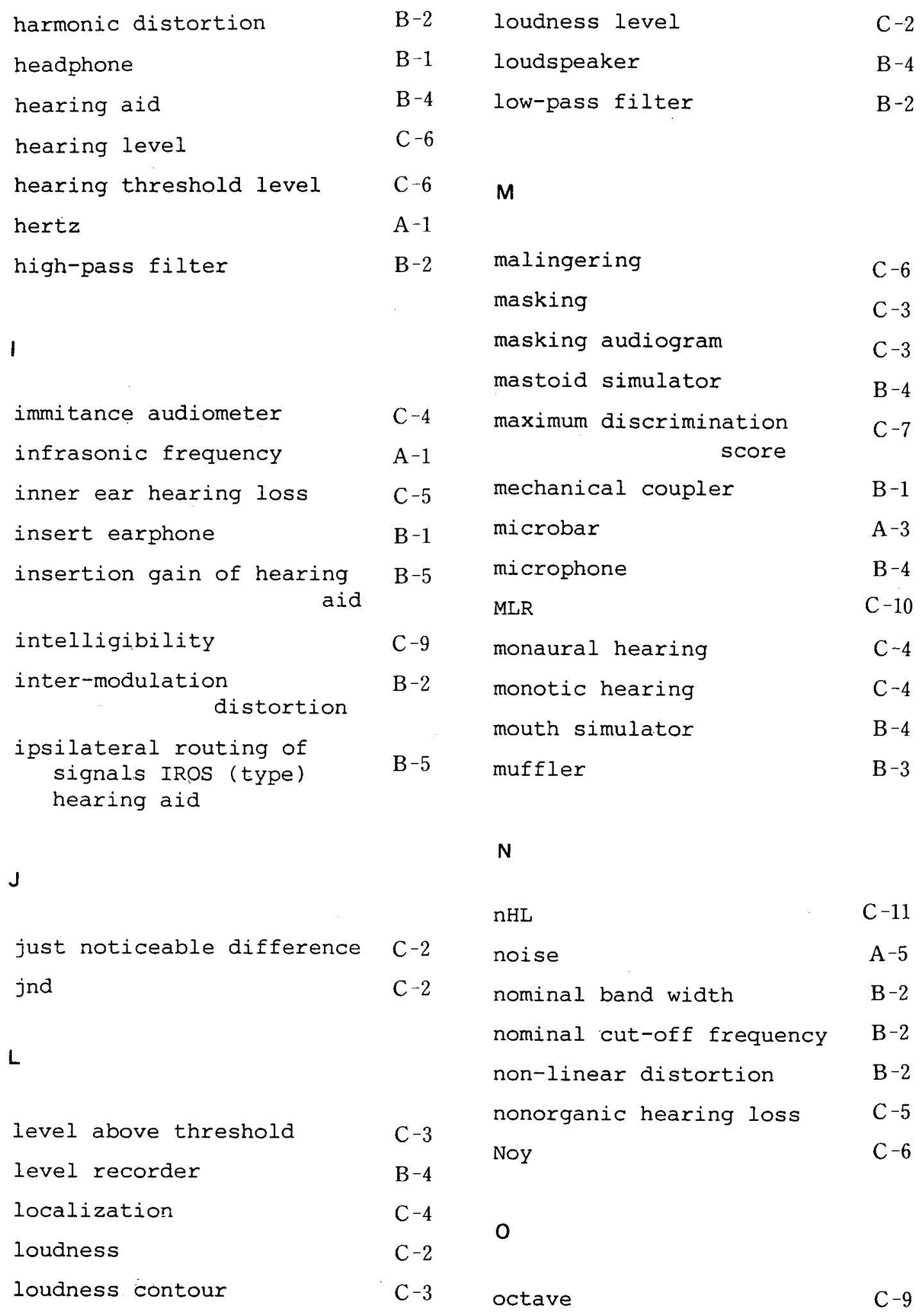




$\begin{array}{lllr}\begin{array}{l}\text { octave band analyzer } \\ \text { open (canal) earmold }\end{array} & \text { B-3 } & \text { resonance } & \text { A-4 } \\ \text { open ear gain } & \text { B-5 } & \text { resonance frequency } & \text { A-4 } \\ \text { oscillation } & \text { B-5 } & \text { resonant frequency } & \text { A-4 } \\ \text { overtone } & \text { A-6 } & \text { retrocochlear hearing loss } & \text { C-5 } \\ & \text { A-4 } & \text { reverberation } & \text { A-5 } \\ & & \text { reverberaion time } & \text { A-5 }\end{array}$

$\mathbf{P}$

\begin{tabular}{|c|c|c|c|}
\hline partial & $A-3$ & & \\
\hline pascal & $A-3$ & sensation level & $\mathrm{C}-3$ \\
\hline pass band & B -2 & sentence intelligibility & $\mathrm{C}-9$ \\
\hline passing band & $\mathrm{B}-2$ & silencer & $\mathrm{B}-3$ \\
\hline passive transducer & $\mathrm{B}-3$ & simple tone & $A-3$ \\
\hline peak equivalent sound & $\mathrm{C}-11$ & simulated ethymotic gain & $B-5$ \\
\hline pressure level & & simulated insertion gain & $B-5$ \\
\hline percent articulation & $\mathrm{C}-8$ & simulated open ear gain & $B-6$ \\
\hline percent intelligibility & $\mathrm{C}-9$ & simulation & $\mathrm{C}-6$ \\
\hline period & $A-1$ & slow vertex response & C -10 \\
\hline periodic & $A-1$ & sound & $A-1$ \\
\hline pe SPL & $C-11$ & sound analyser & $\mathrm{B}-3$ \\
\hline phase & A-3 & sound analyzer & $\mathrm{B}-3$ \\
\hline phase difference & A-3 & sound articulation & $\mathrm{C}-8$ \\
\hline pink noise & A-5 & sound field & $A-6$ \\
\hline pistonphone & $\mathrm{B}-1$ & sound intensity & $A-2$ \\
\hline pitch & $\mathrm{C}-1$ & sound intensity level & $A-2$ \\
\hline probe microphone & $\mathrm{B}-3$ & sound level meter & $B-4$ \\
\hline psychogenic hearing loss & $\mathrm{C}-5$ & sound pressure & $A-2$ \\
\hline pure sound & $A-3$ & sound pressure level & $A-3$ \\
\hline pure tone & $A-3$ & sound spectrum & $A-3$ \\
\hline & & sound wave & $A-1$ \\
\hline $\mathbf{R}$ & & $\mathrm{SP}$ & $\mathrm{C}-9$ \\
\hline rating sound level & $\mathrm{C}-6$ & spectrum pressure level & $A-3$ \\
\hline recruitment & $\mathrm{C}-3$ & speech audiogram & $\mathrm{C}-7$ \\
\hline
\end{tabular}




\begin{tabular}{|c|c|c|c|}
\hline speech reception threshold & $\mathrm{C}-7$ & unvoiced sound & $\mathrm{C}-7$ \\
\hline SRT & $C-7$ & & \\
\hline standard microphone & B-3 & V & \\
\hline standing wave & $A-4$ & vented earmold & \\
\hline stationary wave & $\mathrm{A}-5$ & vibration & B-5 \\
\hline subharmonic & A-4 & VIDIdLIOH & $A-6$ \\
\hline subjective tone & $\mathrm{C}-1$ & vibration level & A-6 \\
\hline summating potential & $\mathrm{C}-9$ & vibration level meter & B-4 \\
\hline supraaural earphone & $B-1$ & vibration meter & $B-4$ \\
\hline SVR & $\mathrm{C}-10$ & voiced sound & $\mathrm{C}-7$ \\
\hline syllable articulation & $\mathrm{C}-8$ & vowel articulation & $\mathrm{C}-8$ \\
\hline $\mathrm{T}$ & & W & \\
\hline telephone earphone & $\mathrm{B}-1$ & warble tone & A-5 \\
\hline telephone microphone & $\mathrm{B}-4$ & wave filter & $\mathrm{B}-2$ \\
\hline threshold audiogram & $C-4$ & waveform distortion & $B-2$ \\
\hline threshold feeling & $\mathrm{C}-2$ & wavelength & $A-2$ \\
\hline threshold hearing & $\mathrm{C}-2$ & white noise & $A-5$ \\
\hline threshold of audibility & $\mathrm{C}-2$ & $\begin{array}{l}\text { whole nerve action } \\
\text { potential }\end{array}$ & $\mathrm{C}-10$ \\
\hline threshold of tickle & $\mathrm{C}-2$ & word intelligibility & $\mathrm{C}-9$ \\
\hline threshold shift & $C-5$ & & \\
\hline throat microphone & $\mathrm{B}-4$ & & \\
\hline timbre & $\mathrm{C}-1$ & & \\
\hline tone burst & $\mathrm{C}-10$ & & \\
\hline tone pip & $\mathrm{C}-11$ & & \\
\hline transducer & $\mathrm{B}-3$ & & \\
\hline transient distortion & $\mathrm{B}-2$ & & \\
\hline tuning fork & $\mathrm{B}-1$ & & \\
\hline \multicolumn{4}{|l|}{$U$} \\
\hline ultrasonic wave & $A-1$ & & \\
\hline ultrasound & $A-1$ & & \\
\hline
\end{tabular}

